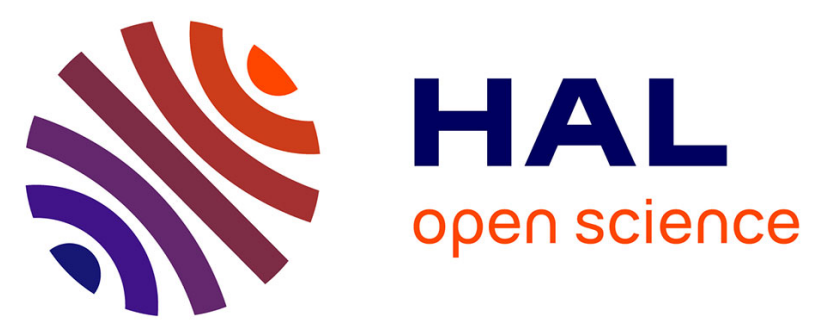

\title{
Mapping of a buried basement combining aeromagnetic, gravity and petrophysical data: The substratum of southwest Paris Basin, France
}

Julien Baptiste, Guillaume Martelet, Michel Faure, Laurent Beccaletto, Pierre-Alexandre Reninger, José Perrin, Yan Chen

\section{To cite this version:}

Julien Baptiste, Guillaume Martelet, Michel Faure, Laurent Beccaletto, Pierre-Alexandre Reninger, et al.. Mapping of a buried basement combining aeromagnetic, gravity and petrophysical data: The substratum of southwest Paris Basin, France. Tectonophysics, 2016, 683, pp.333-348. 10.1016/j.tecto.2016.05.049 . insu-01339986

\section{HAL Id: insu-01339986 \\ https://hal-insu.archives-ouvertes.fr/insu-01339986}

Submitted on 1 Jul 2016

HAL is a multi-disciplinary open access archive for the deposit and dissemination of scientific research documents, whether they are published or not. The documents may come from teaching and research institutions in France or abroad, or from public or private research centers.
L'archive ouverte pluridisciplinaire HAL, est destinée au dépôt et à la diffusion de documents scientifiques de niveau recherche, publiés ou non, émanant des établissements d'enseignement et de recherche français ou étrangers, des laboratoires publics ou privés.

\section{(1) (1) $\$$}

Distributed under a Creative Commons Attribution - NonCommercial - NoDerivatives 44.0 
1 Mapping of a buried basement combining aeromagnetic, gravity

2 and petrophysical data: the substratum of southwest Paris

3 Basin, France

4

5

*Julien Baptiste ${ }^{1,2}$, Guillaume Martelet ${ }^{2}$, Michel Faure ${ }^{1}$, Laurent Beccaletto ${ }^{2}$,

6

Pierre-Alexandre Reninger ${ }^{2}$, José Perrin ${ }^{2}$, Yan Chen ${ }^{1}$,

7

$8{ }^{1}$ Institut des Sciences de la Terre d'Orléans, UMR 7327, Université d'Orléans, Campus

9 Géosciences, $1 \mathrm{~A}$ rue de la Férollerie, 45071 Orléans Cedex 2

$10{ }^{2}$ Bureau de Recherche Géologique et Minière (BRGM), UMR 7327, 3 avenue Claude 11 Guillemin, BP 36009, 45060 Orléans Cedex 2.

12 * Corresponding author: j.baptiste@brgm.fr 


\section{Abstract}

16 Aeromagnetic and gravity data have proven to be among the most effective methods for

17 mapping deeply buried basin/basement interfaces. However, the data interpretation

18 generally suffers from ambiguities, due to the non-uniqueness of the gravity and magnetic

19 signatures. Here, we tie the gravity and magnetic signatures with a petrophysical

20 characterization of the lithologies outcropping around the French Paris Basin. Our

21 methodology investigates the lithology and structure of its hidden Variscan substratum at

22 the junction between the Armorican Massif and Massif Central. Our approach is based on

23 the combination of potential field data, magnetic susceptibilities measured in the field,

24 density values of sample rocks and information documented in boreholes, in order to

25 propose a new interpretative geological map of the buried substratum of the Paris Basin.

26 The petrophysical description is combined with geophysical patterns of the substratum,

27 mapped through statistical unsupervised classification of suitably selected magnetic and

28 gravity maps. The first step of interpretation consists in extending the outcropping major

29 structures below the Meso-Cenozoic sedimentary cover of the Paris Basin. The litho-

30 structural units, in between these major structures, are then interpreted separately. The

31 second step consists in assigning lithologies within each unit, with respect to its

32 magnetization and density (as derived from the petrophysical compilation), and mapping its

33 extension under cover, integrating punctual borehole information. Overall, with a special

34 emphasis on relating geophysical signatures and petrophysical characteristics of litho-

35 structural units, this methodology permits a precise structural and lithological cartography of

36 a segment of the buried Variscan substratum. In the southwestern part of the Paris Basin,

37 this approach reveals: i) the limited eastward extension of Central Brittany, ii) the eastward

38 extension of the major Cholet fault, iii) the emphasis on N150E-N160E striking fault and 
39 their N30E conjugates, controlling the opening of Permo-Carboniferous basins, and iv) the

40 eastward extension of the Eo-Variscan suture.

41 Keywords: aeromagnetic, gravity, Paris Basin, Variscan substratum, petrophysical data,

42 undercover mapping

\section{1. Introduction}

44 The European Variscan belt belongs to a several thousand-km-long Late Paleozoic orogen

45 extending from the Appalachians in the eastern North America, to Polish Sudetes, through

46 the Mauritanides in West Africa. This belt, formed by Proterozoic to Carboniferous rocks,

47 constitutes the Pre-Mesozoic basement of a large part of Western and Central Europe. In

48 France, the Variscan belt presently crops out in several massifs, namely: Massif Central,

49 Armorican, Ardennes, and Vosges Massifs and in the basement of the Cenozoic Alpine and

50 Pyrenean belts. The continuity between these massifs is hidden by several Mesozoic to

51 Cenozoic sedimentary basins, such as the Paris or Aquitaine Basin (Fig. 1)

52 The Paris Basin is an intraplate sedimentary basin, set up on the Variscan substratum that

53 crops out in the above massifs (Pomerol, 1978; Mégnien; 1980, Perrodon and Zabek, 1990;

54 Guillocheau et al., 2000; Chantraine et al., 2003) (Fig. 1). It is well known that lithologies

55 and structures of the southern part of the Armorican Massif and the Massif Central are

56 closely related (Autran and Lameyre, 1980; Matte and Hirn, 1988; Virlogeux et al., 1999;

57 Faure et al., 2005; Cartannaz et al., 2006; Gébelin et al., 2007; Ballèvre et al., 2009; Rolin

58 et al., 2009); however, their connection is still poorly known, as it hidden by the Meso-

59 Cenozoic Paris Basin sedimentary cover. Both massifs are composed of several litho-

60 tectonic units separated by crustal-scale shear zones, such as the North Armorican Shear

61 Zone (NASZ) and the South Armorican Shear Zone (SASZ), in the Armorican Massif or the

62 Marche Fault in the Massif Central (Fig. 1). In addition, the Nort-sur-Erdre fault of the 
63 Armorican Massif (NSE F.; Fig. 1) is acknowledged as the Eo-Variscan suture (Fig. 1)

64 (Matte, 1986; Le Corre et al., 1991; Ballèvre et al., 1992; Lardeux and Cavet, 1994; Faure

65 et al., 1997; Cartier et al., 2001; Bitri et al., 2003). The eastward extension of the Armorican

66 litho-structural units has already been integrated in large-scale geodynamic reconstructions

67 of the Variscan belt, either based on geological evidence (e.g. Matte, 1986; Faure et al.,

68 2005; Ballèvre et al., 2009; Martínez-Catalán, 2012, Edel et al., 2015) or on low to medium-

69 resolution regional geophysics (e.g. Edel, 2008). There is no agreement on the limits and

70 nature of the units, and geodynamic significance is still under debate. A way to ascertain

71 these models would be to fill the geological observation gap caused by the Meso-Cenozoic

72 sedimentary cover of the Paris Basin by new high resolution data.

73 In the second half of the $20^{\text {th }}$ century, the Paris Basin substratum started being investigated

74 using gravity data (Goguel and Francia, 1954), deep boreholes (Lienhardt, 1961) or deep

75 seismic profiles (Matte and Hirn, 1988). A combination of gravity and intermediate to low

76 resolution aeromagnetic data was used in the southwestern part of the Paris Basin

77 (Weber, 1973). The extension of this last study to the entire Paris Basin led to the first

78 version of a pseudo-lithological and structural sketch of the pre-Mesozoic substratum of the

79 Paris Basin (Debeglia and Weber, 1980). More recently, on the basis of the combination of

80 new high resolution magnetic data and updated gravity data, Martelet et al., (2013)

81 proposed a method to characterize the substratum geometry of the central-south part of the

82 Paris Basin, but no detailed lithological interpreted map was produced yet.

83 In addition, a map of the buried substratum around the Poitou High was proposed on the

84 base of detailed structural analysis and drilling information (Rolin and Colchen, 2001).

85 Because we now benefit from recent high resolution aeromagnetic data on the entire

86 southwestern part of the Paris Basin, we are now able to address the litho-structural pattern

87 of its buried substratum with an unprecedented resolution. Complemented by a 
88 characterization of the field petrophysical properties of the various litho-structural units, our

89 work ascertain cartographic interpretations of the geophysical signatures. Our methodology

90 emphasizes the processing of interpretation of potential field data to derive a high-

91 resolution structural map. Combining the latter with field petrophysical properties, lithologies

92 were then interpreted in each litho-structural unit, leading to a new geological map of the

93 Paris Basin substratum.

94 The extensions of the litho-structural units as well as the lithologies of the Variscan and 95 their regional geological implications are further discussed.

\section{2. Geological setting}

98 The Paris Basin is a low subsidence Meso-Cenozoic sedimentary basin. It is composed of 99 silico-clastic and calcareous rocks (Pomerol, 1978; Mégnien, 1980; Perrodon and Zabek, 100 1990; Guillocheau et al., 2000; Beccaletto et al., 2011). It is set up on a Variscan 101 substratum including Permo-Carboniferous basins. In the study area, the formations 102 constituting the Variscan substratum of the Paris Basin laterally outcrop in the Armorican 103 Massif to the west and the Massif Central, to the south, respectively (Fig. 2a).

104 The Armorican Massif is composed of several litho-structural units separated by crustal105 scale faults and characterized by distinct lithologies and tectonic evolutions (Fig. 2a). The 106 North Armorican Shear Zone (NASZ; Chauris, 1969; Watts and Williams, 1979), the 107 northern and the southern branches of the South Armorican Shear Zone (NBSASZ and 108 SBSASZ, respectively) (Jégouzo, 1980) and the Nort-sur-Erdre fault (NSE) are the main 109 Variscan structures of the central and southeastern part of the Armorican Massif (Fig. 2a). 110 The NASZ and the SBSASZ delimit the Central Brittany to the north and south, respectively 111 (Fig. 2a). Central Brittany consists of folded and weakly metamorphosed Neoproterozoic 
112 sediments, unconformably overlain by weakly deformed Paleozoic sediments, intruded by

113 Carboniferous granites (Fig. 2b) (Vernhet et al., 2009). Located along the NASZ, the

114 southerly early Carboniferous Laval basin is superimposed on the Neoproterozoic to

115 Paleozoic series (Fig. 2b). It is composed of early Carboniferous sedimentary rocks

116 interbedded with acidic and basic volcanic rocks (Le Hérissé and Plaine, 1982). The Laval

117 basin was folded during the Late Carboniferous (Houlgatte et al., 1988).

118 Between the NBSASZ and the NSE fault, the Paleozoic series of the St-Georges-sur-Loire

119 unit overthrusts to the NW the Lanvaux unit (Fig. 2a). The NW-SE striking Lanvaux unit is

120 composed of Neoproterozoic and early Cambrian metasediments overlain by Paleozoic

121 weakly metamorphosed sediments (Lardeux and Cavet, 1994), and intruded by an early

122 Ordovician granite deformed into an orthogneiss (Fig. 2b), called the St-Clément-de-la-

123 Place (Vidal, 1980). This orthogneiss is intruded by two granitic plutons: i) the Bécon

124 granite (Chauris and Lucas, 1964; Cavet et al., 1970, 1976) and ii) the St-Lambert

125 granodiorite showing S/C structures, emplaced during to the Carboniferous dextral shearing

126 of the NBSASZ (Faure and Cartier, 1998). The Lanvaux unit experienced a polyphase

127 deformation (Faure and Cartier, 1998). The foliation attitude documents an antiform, the

128 core of which is constituted by the orthogneiss. Outcropping at the junction between the

129 Lanvaux and St-Georges-sur Loire unit, the Questembert leucogranite, emplaced during the

130 late Carboniferous (Tartèse et al., 2011a, 2011b) is a syn-tectonic granite related to the

131 SASZ shearing (Berthé et al., 1979; Bernard-Griffiths et al., 1985).

132 To the south, the St-George-sur-Loire unit is divided into two sub-units (Fig. 2a): the blocky

133 sub-unit in the south overthrusts to the NW the northerly Sandstone-Pelite sub-unit (Cartier

134 et al., 2001; Cartier and Faure, 2004).

135 The south of Nort-sur-Erdre fault is a metamorphic nappe stack: described in the southern 136 part of the Armorican Massif (Burg, 1981; Matte, 1991; Bosse et al., 2000; Le Hébel et al., 
137 2002) and in the northern part of the Massif Central (Quenardel and Rolin, 1984; Faure et

138 al., 1990). The structure and the lithology of the metamorphic Champtoceaux Complex in

139 the Armorican Massif and of the Aigurande Plateau in the Massif Central are quite similar

140 (Fig. 2b) (e.g. Faure et al., 2005; Ballèvre et al., 2009). However the Armorican Massif

141 exposes peculiar units absent in the Massif Central. The uppermost unit of the nappe stack,

142 called the Mauges nappe (Fig. 2a), consists of Neoproterozoic metagrauwackes

143 interbedded with meta-volcanics (Wyns and Le Métour, 1983; Cabanis and Wyns, 1986;

144 Wyns et al., 1998), and unconformably overlain by Cambrian sedimentary rocks and felsic

145 volcanites, and Ordovician sandstones (Fig. 2b). This Paleozoic sedimentary and volcanic

146 series is widely exposed in the Choletais area (Cavet et al., 1966). The Cambrian Thouars

147 microgranitic massif associated with basic rocks (gabbros, quartz diorites) intrudes within

148 the Neoproterozoic micaschists, the volcanic series and the dyke complex (Fig. 2b;

149 Thiéblemont et al., 1987, 2001). To the north of the Mauges nappe, the Ancenis basin is

150 located along the NSE fault (Fig. 2a). It is made of Devonian to early Carboniferous

151 deposits (Fig. 2b) (Cavet et al., 1971; Ballèvre and Lardeux., 2005), superimposing the

152 Neoproterozoic micaschists (Fig. 2b).

153 Another unit, exposed uniquely in the Armorican Massif is the "Drain Unit" consisting of 154 serpentinite, gabbro, basalt and siliceous sedimentary rocks, interpreted as dismembered 155 ophiolites along the Eo-variscan suture (Marchand, 1981; Ballèvre et al., 1994; Faure et al., 156 2008). The underlying unit, called the Champtoceaux complex, is an imbrication of crustal157 scale thrust sheets characterized by highly deformed and metamorphosed gneiss and 158 eclogites (Marchand, 1981; Ballèvre et al., 1989, 1994; Bosse et al., 2000). Lastly, the 159 lowermost unit exposed in this area consists of a micaschist and paragneiss suite, named 160 the Mauves-sur-Loire series (Fig. 2b). The entire stack of nappes from the Mauges nappe 161 to the Mauves-sur-Loire series is folded in a km-scale antiform with a steeply eastward 
162 plunging axis probably related to the dextral shearing of the SASZ (Martelet et al., 2004).

163 Carboniferous plutons occupy the core of this antiform (e.g. Wyns et al., 1998).

164 The Aigurande Plateau also consists of a stack of metamorphic nappes, refolded as 165 an ENE-SSW striking antiform, and intruded by several two-mica granitic plutons 166 (Quenardel and Rolin, 1984; Faure et al., 1990). From top to bottom, the litho-tectonic units 167 are characterized by: i) the Upper Gneiss Unit (UGU) composed of a bimodal magmatic 168 series, named leptynite-amphibolite complex with eclogites, and migmatites; ii) the Lower 169 Gneiss Unit (LGU) made of metagrauwackes, micaschists, metarhyolites and amphibolites 170 that never experienced a HP metamorphism; iii) the Para-autochthonous Unit composed of 171 low-grade micaschists (Fig. 2b). The left-lateral Marche fault, main Variscan structure of the 172 northern part of the Massif Central (e.g. Quenardel and Rolin, 1984), is the southern 173 boundary of the Aigurande Plateau (Fig. 2a). A reasonable correlation between the 174 Champtoceaux Complex and the Mauves-sur-Loire Unit in the Armorican Massif and the 175 UGU and LGU in the Massif Central, respectively has been proposed (e.g. Faure et al., 176 2005).

Previous structural and lithological analyses within the Poitou High (Rolin and 178 Colchen, 2001) documented the close connection between the Haut Bocage unit and the 179 Confolentais area. In the Poitou High, the substratum that crops out in rare valleys is made 180 of Carboniferous granite. Below the sedimentary cover of the Poitou High, the SBSASZ 181 eastward extension splits into several branches which separate structures and lithologies of 182 the Haut Bocage and Confolentais units (Fig. 2a) (Rolin and Colchen, 2001). The Haut 183 Bocage unit is composed of anatectic gneiss and Neoproterozoic micaschists (Fig. 2b). The 184 Confolentais unit is made of granites, metavolcanites and metasediments belonging to the 185 UGU (Fig. 2b). Both units are intruded by late Devonian gabbro, granodiorites and diorites 186 that also crop out along the left-lateral Marche fault (Peiffer, 1986; Cuney et al., 1993; Pin 
187 and Paquette, 2002). In the Confolentais area can be found the westernmost expression of 188 the Limousin tonalite belt (Bernard-Griffiths et al., 1985; Peiffer, 1986).

\section{3. Aeromagnetic and gravity data}

\subsection{Processing of aeromagnetic data}

192 Magnetic measurements monitor the spatial variations of magnetic properties of the 193 underground, from the surface of the Earth down to several kilometers. The French

194 Geological Survey (BRGM) conducted a fixed-wing magnetic survey in 1998 over Brittany 195 (Bonijoly et al., 1999; Truffert et al., 2001) and from August 2008 to October 2010 over the 196 Pays de la Loire (PaL) and Région Centre (Martelet et al., 2013) covering the Armorican 197 Massif and the southwestern part of the Paris Basin (Fig. 3a). These surveys were flown at 198 an average $85 \mathrm{~m}$ and $120 \mathrm{~m}$ ground clearance for Région Centre, PaL and Brittany, 199 respectively. For the three surveys, the flight path was oriented N-S, with a line-spacing of $200500 \mathrm{~m}$ reduced to $250 \mathrm{~m}$ over key areas for the Brittany survey and $1 \mathrm{~km}$ reduced to $500 \mathrm{~m}$ 201 for PaL and Région Centre surveys; perpendicular control tie lines were also flown every $20210 \mathrm{~km}$. The surveys overlap with each other on a 3 to $5 \mathrm{~km}$ band at their periphery. In order 203 to get rid of punctual artifacts related to human activities, the data were upward continued 204 to an elevation of $600 \mathrm{~m}$. This removed the short wavelength cultural noise without 205 significantly smoothing the data, with regards to the aims and regional extent of the study. 206 Magnetic anomaly $250 \mathrm{~m}$ regular grids were produced using the minimum curvature 207 gridding method (Taylor and Mason, 1972), separately, for each survey.

208 In addition three grid transforms were applied to emphasize various properties of the buried 209 substratum:

$210 \quad-\quad$ The reduction to the pole (RTP; Fig. 3b): it contributes to simplify the magnetic signal 211 interpretation (Blakely, 1996). Taking into account the Earth field direction, this 
operator relocates the magnetic anomaly on top of its causative body. When induced magnetization predominates, anomaly bipolarities are removed, so that RTP positive anomalies indicate a local increase of magnetic susceptibility at depth.

- The vertical derivative (Fig. 3c): it enhances local signal gradients while regional trends are removed. Magnetization in the Meso-Cenozoic Paris Basin is weak and sedimentary cover thickness vary smoothly over large distances; therefore, they generate long wavelength components in the magnetic map, which are removed by the vertical gradient operator. Consequently the map of the magnetic vertical gradient highlights the magnetic contrasts within the underlying substratum (e.g. Weber, 1973; .Martelet et al., 2013).

- The Tilt derivative (TILT) or Tilt angle processing (e.g. Miller and Singh, 1994; Verduzco et al., 2004) is powerful for structural interpretation as it depicts equally the edge of deep and shallow magnetic sources (Miller and Singh, 1994). It is an effective method for mapping contacts or faults, weakly contrasted magnetized bodies, located under a sedimentary cover (Fairhead et al., 2011). The TILT map was used to highlight the structures of the underlying substratum and the magnetic body contours which are defined by the zero value in the TILT map (Fig. 3d).

230 reduced to the pole (RTP). In order to avoid artifacts at survey junctions, the magnetic 231 transforms were applied separately, survey by survey, before merging. The merge of the 232 three magnetic surveys was carefully achieved, using a standard grid stitching algorithm.

\subsection{Processing of gravity data}


235 Gravity data derive from the compilation of ground gravity surveys conducted in France 236 since the middle of the 20th century and compiled in the Banque Gravimétrique de la

237 France (BGF) (Martelet, et al., 2009). In the study area, the average station coverage is 238 about 1 station $/ \mathrm{km}^{2}$. Data are tied to the CGF65 base station network. In order to derive the 239 Bouguer anomaly, all standard corrections are included, with a reference density of $2402600 \mathrm{~kg} / \mathrm{m3}$, and terrain corrections computed to a distance of $167 \mathrm{~km}$ (Martelet et al., 241 2002). Taking into account the accuracy of 1) the network, 2) the gravity measurements

242 and their positioning and 3) the terrain corrections, the RMS error on the Bouguer anomaly 243 is $0.32 \mathrm{mGal}$ in the study area. The Bouguer anomaly map presented in Fig. 4a locates the 244 main regional density contrasts, from the surface down to several kilometers at depth.

245 A map of the vertical derivative of the Bouguer anomaly is presented in Fig. 4b. The first 246 order of the vertical gradient of the Bouguer anomaly has long been used for separating 247 close structures (Elkins, 1951; Gérard and Griveau, 1972; Goguel, 1972). Here, this 248 operator is used to highlight density contrasts within the Paris Basin substratum. As for the 249 magnetic map, the regional effect of the Meso-Cenozoic sedimentary pile results in smooth 250 and long wavelength signals and is therefore strongly attenuated by this operator (see 251 Martelet et al., 2013 for more details). Positive and negative signals of the vertical gradient 252 feature relatively high and low density rocks at depth, respectively.

\section{4. Measurements of field rock properties}

255 Gravity and magnetic map usually display "averaged” geophysical signatures of geological 256 bodies as compared to the lithological variations at the outcrop scale; the discrimination of

257 the magnetic and gravity causative lithologies suffering from ambiguities. An extensive 258 campaign of petrophysical sampling and measurements was conducted in order to take into 
259 account this scale effect in our geophysical maps interpretation. It was designed to derive 260 reliable petrophysical "statistic signatures" for the main lithologies encountered in the study 261 area.

\section{$263 \quad 4.1$ Magnetic susceptibility}

264 The magnetic susceptibility of a rock refers to its ability to become magnetized by an 265 external magnetic field such as the Earth's field (e.g. Dearing, 1999). Rocks have various 266 magnetic responses due to their magnetic properties, which to the first order, depend on 267 the volume content of magnetite (Clark and Emerson, 1991). Magnetic susceptibility field 268 measurements were carried out using a hand-held kappameter (KT-9, Exploranium, 269 Canada). The measuring range of KT-9 susceptibility meters is from -999 to $999 \times 10-3 \mathrm{SI}$

270 units with a sensitivity of $1 \times 10-5 \mathrm{SI}$. Because reproducibility of measures is influenced by 271 the irregularity of the rock surface (Lecoanet et al., 1999), measures were achieved in the 272 "Pin-mode" of the kappameter which takes into account a geometric factor to reduce 273 roughness effects.

274 About 4050 magnetic susceptibility measurements were taken directly on 130 outcrops, all 275 along the southeastern border of the Armorican Massif and the northwestern border of the 276 Massif Central and Poitou High (Fig. 3a). Within each litho-structural unit, most of the 277 outcropping lithologies were sampled. The compilation of these measurements is presented 278 in Fig. 5. For each litho-structural unit, we numerated the magnetic susceptibility 279 measurements within constant intervals of variation. In Fig. 5, the colored bars highlight the 280 most represented magnetic susceptibility ranges, whereas the grey intervals indicate 281 ranges with few randomly distributed data. 
282 As an aid for the interpretation, the magnetic susceptibility was subdivided into three 283 representative ranges, based on the classification of Clark and Emerson (1991) and the 284 separation range of Théveniaut and Clarke, (2013): i) from negative values to $4 \times 10-4 \mathrm{SI}$, ii) 285 from $4 \times 10-4$ to $5 \times 10-3 \mathrm{SI}$ and iii) above $5 \times 10-3 \mathrm{SI}$, designated as low, intermediate and 286 high magnetic susceptibility ranges, respectively. Fe-rich sandstones in Central Brittany 287 exhibit the highest magnetic susceptibility of the study area (Fig. 5). Basic rocks (gabbro288 diorite, granodiorite and amphibolite), and Cambrian felsic volcanites are also within the 289 high magnetic susceptibility range, due to their high amount of ferrimagnetic minerals, such 290 as magnetite, in their mineralogical composition (Thiéblemont et al., 2011). Granite, 291 leptynite, orthogneiss, migmatite, Neoproterozoic metasedimentary and Paleozoic 292 sedimentary rocks, micaschists and metasediments are within the low magnetic 293 susceptibility range, given that they are mainly composed of diamagnetic (quartz, 294 plagioclase) and paramagnetic minerals. Some Paleozoic sedimentary rocks, basalts, 295 metabasites, meta-gabbro, diorites and amphibolites are within the intermediate range, 296 since they contain paramagnetic minerals, and a small amount of iron-bearing minerals 297 (amphibole, biotite or clay minerals).

298 Induced magnetization is predominant in the area, but several bimodal anomalies in the 299 RTP map (Fig. 3b) indicate some remnantly magnetized rocks. To the north, the Fe-rich 300 Ordovician sandstones of Central Brittany, mainly composed of magnetite, have been 301 studied in detail (Corpel and Weber, 1970): their Koenigsberger ratio is around 6 but the 302 remnant component of magnetization is almost collinear to the ambient magnetic field and 303 therefore does not strongly affect the mapping of this unit. Also, the granodiorite within the 304 Choletais area and the diorite plutons within the Confolentais area are partly remnantly 305 magnetized, but their magnetic anomalies almost perfectly match their field cartographic 306 limits (Fig. 3b). This suggests that i) the effect of the remnant magnetization is weak, or ii) 
307 their direction of remnant magnetization is close to the induced magnetization. In these

308 three cases, the location of the magnetic causative bodies is only slightly affected by the

309 remnant magnetization and these lithologies also display a high magnetic susceptibility in

310 the field (Fig. 5). Consequently, we made the assumption that the interpretation of the

311 magnetic maps could be achieved considering the magnetic susceptibility only.

312 Globally, there is a significant overlap between the magnetic susceptibility ranges of the

313 various lithologies; however, this overlap is rather limited between lithologies within each

314 litho-structural unit. This observation is crucial for the geophysical maps interpretation, as

315 described in the following paragraphs.

\section{$316 \quad 4.2$ Density}

317 Density is the petrophysical property influencing the gravity data. For this study, 54

318 unweathered rock samples from most of the lithologies were collected all along the

319 Armorican and Massif Central borders in 48 outcrops (Fig. 3a). The densities of these

320 samples were measured using the double weighting method, with a ca. $0.01 \mathrm{~g} / \mathrm{cm}^{3}$

321 uncertainty. The density determination of some lithologies was not possible due to bad

322 outcropping conditions. In this case, a density value was affected with respect to the density

323 average of the same lithology in the other litho-structural units.

324 As for the magnetic susceptibilities, the densities were subdivided into three representative

325 groups: i) from 2.55 to $2.65 \mathrm{~g} / \mathrm{cm}^{3}$, ii) from 2.65 to $2.8 \mathrm{~g} / \mathrm{cm}^{3}$, and iii) above $2.8 \mathrm{~g} / \mathrm{cm}^{3}$ for 326 low, intermediate and high densities, respectively (e.g. Edel, 2008) (Fig. 5). 
329 The previous studies investigating the substratum of the Paris Basin using magnetic and 330 gravity data manually outlined the main geophysical anomalies. They were interpreted with 331 simplified lithological attributions, based on the substratum nature documented in some 332 boreholes as well as some rock property data (Weber, 1973; Debeglia and Weber, 1980).

333 More recently, Martelet et al., (2013) proposed a map of petrophysical signatures of the 334 substratum of the south-central part of the Paris Basin, based on a numerical classification 335 combining gravity and magnetic data. We used the same approach to achieve a simplified 336 magnetic-gravity signature of the substratum of the study area.

337 We agree with previous studies that considered the magnetic effect of the Meso-Cenozoic 338 sedimentary cover of the Paris Basin, almost "transparent" for the magnetic field 339 (Weber, 1973); therefore the magnetic map mostly features the buried substratum. 340 Nevertheless the Meso-Cenozoic sedimentary pile at least attenuates the intensity of the 341 magnetic response of the substratum and increases the wavelength of the substratum 342 anomalies, as the sedimentary cover gets thicker; from 0 to about $2000 \mathrm{~m}$ in the study area. 343 The gravity field contains both the effects of the substratum and of the sedimentary basin.

344 The vertical gradient of the Bouguer anomaly used for our classification attenuates the long 345 wavelengths of the Meso-Cenozoic sedimentary pile (Debeglia and Weber 1985; Martelet 346 et al., 2013). Aiming at the same goals as Martelet et al., (2013), the map of the magnetic 347 anomaly reduced to the pole that was introduced in our classification, followed two 348 considerations: 1) displaying information of the structure and magnetization of the 349 substratum as detailed as possible; 2) being physically as homogeneous as possible with 350 the gravity first vertical derivative. We added a third consideration: 3 ) reducing as much as 351 possible the variable smoothing and attenuating effect of the Meso-Cenozoic sedimentary 352 pile. Combining the characteristics of RTP and the TILT fulfils the three conditions. These 353 two magnetic maps were combined with the vertical gradient of the Bouguer anomaly to 
354 obtain synthetized signatures of magnetic and gravity data. The three layers were 355 combined into a ternary image, using a standard image fusion procedure. We then

356 performed a numerical classification of this ternary image using unsupervised isodata 357 clustering (e.g. Venkateswarlu and Raju, 1992). Based on their gravity and magnetic 358 signatures, all pixels of the map were statistically distributed among 6 classes (Fig. 6a) 359 which well figure the geophysical signatures of the outcropping geology. This map displays 360 self-consistent cartographic bodies, which are compatible with known geological patterns. It

361 features 2 levels of magnetic intensity (from light to dark green) and an intermediate 362 average magnetic/gravity signature (in white) as well as 3 levels of gravity intensity (from 363 light to dark blue). These synthetized geophysical signatures can be related to the 364 simplified 3-levels categorization of the petrophysical magnetization/density parameters 365 (Fig. 5). This map combines magnetic and gravity signatures and it is used as a support for 366 the following structural and lithological interpretations.

\section{Geological map of the pre-Mesozoic substratum}

369 The first step of the interpretation consists in extending below the Paris Basin sedimentary 370 cover the major structures recognized in the field (Fig. 2a) in order to delineate the Variscan

371 litho-structural units under cover. The structural interpretation (Fig. 6b) uses all geophysical 372 enhanced maps presented in Section 3 supported by the synthetized geophysical 373 signatures map (Fig. 6a). The second step consists in interpreting the lithological nature of 374 the hidden substratum, using the combined petrophysical characteristics of rocks (Fig. 5), 375 the synthetized geophysical signatures of the substratum (Fig. 6a) and the structural sketch 376 map including available boreholes (Fig. 6b). 


\subsection{Undercover delineation of structural features}

378 Manually interpreted geophysical trends deriving from the magnetic and gravity maps are

379 outlined in red in Fig. 6a. They underline the N110E-N120E and N90E striking structural

380 directions of the Armorican Massif and the Massif Central, respectively, known in the field.

381 In addition to these trends, main geophysical structures and discontinuities were

382 interpreted. The interpretative structural map (Fig. 6b) showing the extension of the

383 structural units below the Paris Basin cover is discussed from north to south.

384 Central Brittany is limited to the north by the NASZ. Its extension constitutes the northern

385 limit of the study area; it is defined regionally by a major $\mathrm{N} 110^{\circ} \mathrm{E}$-oriented disharmony 386 between the strong magnetic signals of Central Brittany to the south, and the northern weak 387 magnetic signals (Fig. 3b). It also outlined by a successive E-W striking chaplet of magnetic 388 anomalies bounded the NASZ to the north, which can be outlined from the field to the 389 easternmost part of the studied area (Baptiste et al., 2015) (Fig. 3c, Fig. 3d). The Lanvaux 390 unit is marked by a well-defined NW-SE striking elongated low density anomaly, known as 391 Lanvaux orthogneiss (Fig. 4b); it is bounded to the north by the NBSASZ. Following the 392 magnetic and gravity trends under cover (Fig. 6a), the strike of the NBSASZ changes 393 eastwards from NW-SE to NE-SW and joins the NASZ, limiting Central Brittany to the east 394 (Fig. 6b). The southern border of the noticeable Lanvaux low gravity anomaly defines the 395 limit between the Lanvaux unit and the northern part of St-Georges-sur-Loire unit (Fig. 6b). 396 In the field, the St-Georges-sur-Loire unit is characterized by low magnetic (Fig. 3b) and 397 gravity signal (Fig. 4b), and by scattered moderate intensity magnetic anomalies (Fig. 3c) 398 and a high intensity gravity anomaly, to the north and south, respectively. Predominant NW399 SE/E-W striking geophysical trends are also observed (Fig. 6b). Under the Paris Basin 400 sedimentary cover, the northern and southern part cannot be separated by geophysical 401 data. The southern border of the high intensity gravity anomaly defines the southern limit of 
402 the St-Georges-sur-Loire unit (Fig. 4b); it defines the cartographic trace of the NSE 403 Eo-Variscan suture (Fig. 6b).

404 The Choletais area, marked by an E-W striking high gravity elongated anomaly, extending $405150 \mathrm{~km}$ eastwards below the Paris Basin sedimentary cover (Fig. 4b), is bounded to the 406 south, by the northern branch of the Cholet fault (Fig. 6b). This noticeable anomaly defines 407 the southward boundary of the Mauges nappe. Along this fault, the magnetic and gravity 408 trends strike $\mathrm{E}-\mathrm{W}$ in continuity along more than $150 \mathrm{~km}$ (Fig. 6a). Northwards, the 409 geophysical trends become less and less continuous (Fig. 6a), suggesting the decreasing 410 gradient of deformation away from the fault, as observed in the Armorican Massif 411 (Thiéblemont et al., 2011). To the east (around $2^{\circ} \mathrm{E}$ ), the E-W striking Cholet fault marks the 412 northern limit of NW-SE geophysical trends of the Aigurande Plateau. Altogether, these 413 features suggest that the Cholet fault can be considered as a major shear zone.

414 In the east of the study area (around $2^{\circ} \mathrm{E}$ ), the NSE fault and the northern branch of the 415 Cholet fault almost meet, closing the Mauges nappe and the Choletais area, to the east 416 (Fig. 6a). To the south of the Cholet fault, low gravity anomalies (Fig. 4b) and signatures 417 (Fig. 6a) and NW-SE striking geophysical trends (Fig. 6a) are predominant; this refers to 418 the Haut Bocage unit and Confolentais area connection. To the east of the Haut Bocage 419 unit, the direction of geophysical trends progressively changes from NW-SE to E-W, 420 featuring the connection between the Haut Bocage unit and Aigurande Plateau.

421 In the easternmost part of the studied area, all these units are interrupted by NE-SW 422 striking structures bounding the Permo-Carboniferous Contres basin, well characterized on 423 seismic profiles and in deep boreholes (Fig. 6b; Beccaletto et al., 2015).

424 At the regional scale, all structures are offset by N150E-N160E-striking faults and, to a 425 lesser extent, by their conjugate N20E-N30E striking faults (Fig. 6b). In agreement with 426 Martelet et al., (2013), two kinematics are interpreted along the N150E-N160E faults: i) a 
427 dextral motion highlighted by the offset of preexisting structures and lithological markers,

428 and ii) a vertical movement documented by the attenuation and the spreading of the

429 magnetic signal from west to east. In the southeastern part of the Armorican Massif, the

430 N150E striking Partenay fault is described as a middle to upper Visean dextral shear zone

431 (Rolin et al., 2009). The seismic information confirms the role of these faults during the

432 opening of Carboniferous or Permian Arpheuilles and Contres basins (Fig. 6b; Beccaletto et 433 al., 2015). Moreover, they were interpreted as Permian or Triassic fracture zones

434 reactivated during the opening of the North Atlantic Ocean and Gulf of Biscaye (Vigneresse,

435 1988). They are also known throughout the Armorican Massif, where they bound small 436 Tertiary basins. Based on these information, the N150E-N160E striking faults can be 437 interpreted as Variscan faults, reactivated during the tectonic evolution of the Paris Basin, 438 strongly affecting present-day geometry in the southwestern part of the basin.

439 The N30E striking normal faults, mainly located in the Mauges nappe (Fig. 6b), are also 440 interpreted as Variscan structures reactivated during the Permo-Carboniferous, controlling 441 the geometry of the Arpheuilles basin (Fig. 6b; Beccaletto et al., 2015).

\section{$442 \quad 6.2$ Interpretation of the undercover lithologies}

443 Based on the geophysical signatures and the structural information, we propose a 444 geological map displaying the interpreted lithologies assigned to the dominant geophysical 445 signatures (Fig.7a) and an interpretative cross section based on geological information 446 observed in the field (Fig. 7b). This geological map as well as its tectonic implications are 447 discussed in each litho-structural unit.

\section{$448 \quad$ 6.2.1 Central Brittany}

449 Central Brittany is mainly composed of Neoproterozoic metasedimentary rocks and 450 Paleozoic sedimentary rocks intruded by Carboniferous granites (Fig. 2). In this 
451 litho-structural unit, high magnetization and density signatures (Fig. 6a) unambiguously

452 refer to the Fe-rich Ordovician sandstone (up to $0.8 \mathrm{SI}$ and $3.11 \mathrm{~g} / \mathrm{cm}^{3}$; Fig. 5). This marker

453 extends eastwards, bounding the NBSASZ (Fig. 8a); its presence is confirmed at 300m

454 depth under cover by a borehole (Fig. 6b).

455 Contrary to previous models (Weber, 1971, 1973; Debeglia and Weber, 1980), the

456 Paleozoic rocks can be discriminated from the Neoproterozoic ones using the petrophysical

457 information. Paleozoic rocks including Fe-rich sandstones displaying low magnetization and

458 density (from 1.5 to $5 \times 10^{-4} \mathrm{SI}$ and $2.71 \mathrm{~g} / \mathrm{cm}^{3}$; Fig. 5) can be traced eastwards (Fig. 7a). In

459 the field, geophysical signatures of the Neoproterozoic metasedimentary rocks are

460 heterogeneous, with intermediate magnetic susceptibility and low density (from $10^{-4}$ to

$4613 \times 10^{-4} \mathrm{SI}$ and $2.55 \mathrm{~g} / \mathrm{cm}^{3} ;$ Fig. 5). They are also intruded by moderately magnetic and

462 dense $\left(3.11 \mathrm{~g} / \mathrm{cm}^{3}\right)$ gabbroic dykes (Verhnet et al., 2009). Thus the map exhibits a

463 succession of thin E-W trends with intermediate to high magnetic and intermediate gravity

464 signatures that can be identified under the sedimentary cover and grouped with the

465 Neoproterozoic metasedimentary rocks (Fig. 6a). The Laval basin has intermediate to low

466 magnetic and gravity signatures as well as peculiar E-W trending texture (Fig. 6a) well

467 visible in the magnetic vertical gradient (Fig. 3c). This E-W trending signature is likely

468 related to interbedded basalts with intermediate magnetization and density (up to $10^{-2} \mathrm{SI}$

469 and $2.85 \mathrm{~g} / \mathrm{cm}^{3}$; Fig. 5) as observed in the field (Fig. 8b). This feature allows delimiting the

470 southern extension of the Laval basin under the Paris Basin cover (Fig. 8b). Furthermore,

471 the low magnetic and gravity signatures (Fig. 6a) are related to Carboniferous granite

472 intrusions (less than $5 \times 10^{-4} \mathrm{SI}$ and $2.65 \mathrm{~g} / \mathrm{cm}^{3}$; Fig. 5). Witnesses of these granitic plutons

473 are mapped in the field, bounded and affected by the dextral shearing of the NASZ: the

474 Pertre granite emplaced at $343 \pm 3 \mathrm{Ma}$ (Verhnet et al., 2009) and the Craon granite (e.g. Le 
475 Gall et al., 2011; Trautmann et al., 2011). The location and the shape of the undercover 476 granites suggest that they probably are affected by the NASZ shearing (Fig. 8c).

477 Overall, the Central Brittany litho-structural unit, delimited to the south by clear markers of 478 Fe-rich Ordovician sandstones, appears also limited to the east, at the junction between the 479 NASZ and the NBSASZ (Fig. 6b). In the southwestern part of the Paris Basin, these 480 interpretations are consistent with the tectonic sketch of major Armorican shear zones 481 proposed by Martinez Catalàn et al., (2012). The southern part of Central Brittany is 482 structured by patterns of Neoproterozoic and Paleozoic sedimentary rocks. In its 483 northwestern part, the early-Carboniferous Laval basin is developed along the NASZ; it is 484 delimited by low magnetic and gravity signatures (Fig. 6b) related to granitic bodies (Fig. $4857 a)$, to the south.

\subsubsection{The Lanvaux unit}

488 In agreement with previous works, the eastern extension of the Lanvaux negative gravity 489 anomaly (Fig. 4b) is well documented along more than 200 km (Weber, 1973; Debeglia and 490 Weber, 1980; Autran et al., 1994; Martelet et al., 2013). This anomaly is interpreted as 491 deriving from the low magnetization and low density signatures of the Lanvaux orthogneiss, 492 confirmed by the petrophysical measurements (from $10^{-5}$ to $0.7 \times 10^{-4} \mathrm{SI}$ and $2.55 \mathrm{~g} / \mathrm{cm}^{3}$; 493 Fig. 5). In the field, the Carboniferous Bécon and the St-Lambert granites display low 494 magnetic susceptibilities and densities comparable to those of the orthogneiss (from $2 \times$ $49510^{-5}$ to $10^{-4} \mathrm{SI}$; Fig. 5); it is therefore not possible to discriminate the older Lanvaux 496 orthogneiss (477 $\pm 18 \mathrm{Ma}$; Guerrot et al., in Janjou et al., 1998) from the Carboniferous 497 granites. The Carboniferous granites being mainly located along the SBSASZ (Fig. 8c), we 498 consider that the low magnetic and gravity signatures are related to the Lanvaux 
499 orthogneiss (Fig. 8c). Eastwards, under cover, the strike of the NW-SE Lanvaux 500 orthogneiss evolves to an E-W and progressively NE-SW direction, parallel to the NBSASZ 501 (Fig. 8c). Lanvaux unit is an antiform (Faure and Cartier, 1998), with Neoproterozoic 502 metasedimentary and Paleozoic sedimentary rocks similar to those of the Central Brittany

503 and with comparable petrophysical characteristics (Fig. 5). The succession of geophysical 504 signatures of metasedimentary and sedimentary rocks as well as the orthogneiss observed 505 in the field extends eastwards under the Paris Basin sedimentary cover. This suggests that 506 the unit has the same antiformal structure, throughout its eastward extension (Fig. 7b). At 507 the southern border of the Lanvaux unit, the magnetic signature of the Paleozoic rocks 508 highlights the tectonic limit with the St-Georges-sur-Loire unit (Fig. 6b).

510 6.2.3 The St-Georges-sur-Loire unit

511 Whereas cartographically well marked under cover, the eastern extension of the St512 Georges-sur-Loire unit has various geophysical signatures (Fig. 6a), rather magnetic and 513 dense. Cartographically, these signatures cannot be formally related to the 514 northern/southern parts of the unit, as observed in the field (Fig. 2a). The northern part of 515 the unit is marked by low magnetic and gravity signatures (Fig. 6a) related to a granitic 516 pluton (up to $10^{-4} \mathrm{SI}$ and $2.65 \mathrm{~g} / \mathrm{cm}^{3}$; Fig. 5), located at the junction between the Lanvaux 517 and the St-Georges-sur-Loire units, mostly hidden below the Paleozoic series (up to $5 \times 10^{-}$ $518{ }^{4} \mathrm{SI}$ and $2.68 \mathrm{~g} / \mathrm{cm}^{3}$ ). Granites located along the SBSASZ (Fig. 8c) belong to a leucogranite 519 belt displaying dextral shearing, associated with the emplacement of the leucogranite 520 plutons (Berthé et al., 1979; Jégouzo, 1980; Vigneresse and Brun, 1983; Gapais et al., 521 1993; Turillot et al., 2009). Among them, Questembert and Lizio leucogranites (Fig. 8c) emplaced at $316 \pm 3 \mathrm{Ma}$ and $316 \pm 6 \mathrm{Ma}$ (Tartèse et al., 2011b, 2011a), in agreement with 
523 the St-Lambert granite located to the Lanvaux unit, which displays S/C structures

524 suggesting an emplacement during the dextral shearing of the NBSASZ at $312 \pm 3 \mathrm{Ma}$

525 (Faure and Cartier, 1998). Under cover, these low magnetic and gravity signatures are not

526 observed (Fig. 6a), thus these granites cannot be extended eastward, suggesting a limited

527 eastward extension of the leucogranitic belt.

528 The southern part of the unit, the blocky sub-unit is characterized by scattered high 529 magnetic and various low to high gravity signatures (Fig. 6a). Below the Paris Basin 530 sedimentary cover, the high magnetic and gravity signatures elongated eastwards

531 throughout the map, likely correspond to basic rocks, as interpreted by Martelet et al., 532 (2013). These basic rocks can be variously interpreted in terms of lithology: i) basaltic or 533 gabbroic olistostoliths as described in this unit in the Armorican Massif (Cartier and Faure, 534 2004), ii) interbedded basalts related to the opening of a back-arc basin (Ducassou et al., 535 2011) or iii) mafic rocks such as the ophiolites which sporadically crop out along the NSE 536 fault (Marchand, 1981; Faure et al., 2008; Ballèvre et al., 2009). In the eastern part of the 537 St-Georges-sur-Loire unit, the depth of the contact between the substratum and the 538 sedimentary cover is defined at about $500 \mathrm{~m}$, and the bodies responsible for the magnetic 539 signal are located at more than $1500 \mathrm{~m}$ depth (Martelet et al., 2013). Consequently the 540 magnetic susceptibility of the magnetic source has to be strong enough to produce such a 541 magnetic signature. According to the magnetic susceptibility measured in the field in St542 Georges-sur-Loire unit, we cannot interpret the source as basalts since they do not yield a 543 high magnetic susceptibility (from 6 to $8 \times 10^{-4} \mathrm{SI}$; Fig. 5). The third hypothesis better 544 complies with the petrophysical signatures and with other evidence reported in the 545 literature. Indeed, the interpretation of the Armor2 seismic profile, located in the southern 546 part of the Armorican Massif (Bitri et al., 2003), suggested the presence of the northern part 547 of the Champtoceaux complex beneath St-Georges-sur-Loire unit. The northern part of this 
548 complex crops out as ophiolitic series along the NSE fault; it is made of high magnetic

549 susceptibility and high density rocks, such as amphibolite, and micaschists (from 1.1 to 1.5

$550 \times 10^{-2} \mathrm{SI}, 3.02 \mathrm{~g} / \mathrm{cm}^{3}$ and up to $0.3 \mathrm{SI}, 2.79 \mathrm{~g} / \mathrm{cm}^{3}$, respectively; Fig. 5). Therefore, contrary

551 to previous sketch (Weber, 1973; Debeglia and Weber, 1980), our results reveal the

552 eastward extension of ophiolitic series marking the NSE Eo-Variscan suture (Fig. 8d); it is

553 supported by high magnetic and gravity signatures which extend up to the eastern part of

554 the study area limiting St-Georges-sur-Loire unit to the south.

\subsubsection{The Mauges nappe and the Champtoceaux Complex}

557 The Mauges nappe, mainly composed of Neoproterozoic micaschists (Fig. 2), exhibits both

558 low magnetic and gravity signatures (Fig. 6a) that may account for hidden granitic plutons.

559 Granitic rocks crop out locally, as for instance the Chemillé pluton intruding the Mauges

560 micaschists, displaying low magnetic susceptibility and density (up to $8 \times 10^{-4} \mathrm{SI}$ and

$5612.55 \mathrm{~g} / \mathrm{cm}^{3}$; Fig. 5). Similar low geophysical signatures depicted in the undercover

562 extension of the Mauges nappes (Fig. 6a) suggest the presence of punctual granitic

563 plutons, probably similar to the Chemillé granite (Fig. 8c). Also, metabasites interbedded in

564 the micaschists yield higher magnetic susceptibility and density ranges (from 5 to $7 \times 10^{-4}$

$565 \mathrm{SI}$ and $2.82 \mathrm{~g} / \mathrm{cm}^{3}$; Fig. 5) than the surrounding micaschists. These signatures trace the

566 eastward extension of the Mauges nappe under the sedimentary cover of the southern part

567 of the Paris Basin (Fig. 7a).

568 The Choletais area is composed of Cambrian acidic volcanites, intruded by microgranite, 569 granodiorite and gabbro-diorite, unconformably covering the Neoproterozoic rocks (Fig. 2).

570 Among them, the Vézins granodiorite (Fig. 8c) emplaced at $345 \pm 5 \mathrm{Ma}$ (Thiéblemont et al.,

571 2011) is supposed to be a syn-kinematics intrusion related to the dextral shearing of the 
572 Cholet fault (Rolin et al., 2009). In the Choletais area, the magnetic susceptibilities and

573 density measurements do not discriminate the gabbro-diorite suites from the granodioritic 574 plutons (from 4 to $7 \times 10^{-2} \mathrm{SI}, 2.83 \mathrm{~g} / \mathrm{cm}^{3}$ and from 2 to $5 \times 10^{-2} \mathrm{SI}, 2.73 \mathrm{~g} / \mathrm{cm}^{3}$, respectively; 575 Fig. 5). For this reason, these lithologies are grouped together as "basic rocks" in the 576 interpretative geological map (Fig. 7a). The Cambrian volcanics are discrimated by a lower 577 density compared to basic rocks $\left(2.65 \mathrm{~g} / \mathrm{cm}^{3}\right.$ and from 2.73 to $2.83 \mathrm{~g} / \mathrm{cm}^{3}$, respectively; Fig. 578 5). As previously described (Weber, 1971), in the southern part of the Mauges nappe, the 579 northern branch of the Cholet fault is bounded to the north by an unexpected E-W striking 580 high density elongated anomaly, which extends $200 \mathrm{~km}$ eastwards (Fig. 4b). It is 581 superimposed, in the Armorican Massif, to the low magnetization and low density Thouars 582 microgranite (from 1 to $7 \times 10^{-4} \mathrm{SI}$ and $2.65 \mathrm{~g} / \mathrm{cm}^{3}$; Fig. 5). The high intensity anomaly can 583 however be explained by the close association of acidic and basic magmatism composing 584 the Thouars massif (Mathieu, 1943, 1958; Weber, 1971) emplaced at $519 \pm 10 \mathrm{Ma}$ 585 (Thiéblemont, et al., 2011). The high resolution geophysical data enhance this dual 586 anomaly: it highlights punctual high magnetization signatures associated with high density 587 anomaly (Fig. 6a) related to basics rocks (from 3 to $6 \times 10^{-2} \mathrm{SI}$ and up to $2.83 \mathrm{~g} / \mathrm{cm}^{3}$; Fig. 5) 588 and the presence of high density intrusive dolerite $\left(2.97 \mathrm{~g} / \mathrm{cm}^{3}\right.$; Fig. 5$)$ located along the 589 Cholet fault, at the junction between the Mauges nappe and the Haut Bocage unit.

590 The early Carboniferous Ancenis basin is marked by a low gravity anomaly (Fig. 4b) likely 591 related to a hidden granitic pluton (Fig. 8c) as previously described by Martelet et al., (2013) 592 as well as E-W striking high magnetic trends well defined in the vertical gradient of the 593 magnetic anomaly. This contrast can reasonably be related to the northern extension of the 594 Champtoceaux complex, corresponding to the ophiolitic nappe, buried below the Ancenis 595 basin, along the NSE fault, also interpreted in Armor2 seismic profile (Bitri et al., 2003). 
596 Following the NSE fault to the east, the Permo-Carboniferous Arpheuilles basin, recognized

597 by seismic profiles under cover (Beccaletto et al., 2015) and two boreholes (Fig. 6b),

598 exhibits a peculiar texture in the magnetic first vertical derivative (Fig. 3c) and tilt (Fig. 3d)

599 maps. This texture allows delimiting the extension of the Arpheuilles basin (Fig. 8b).

600 Superimposed on the magnetic texture, high intensity magnetic anomalies are interpreted 601 as the presence of Cambrian volcanic rocks (Fig. 7a) underlying Arpheuilles basin, 602 accompanied by granitic plutons highlighted by their low gravity signatures (Fig. 6a). Our 603 results show that, to the north, Arpheuilles basin is bounded by the NSE fault and controlled 604 by N150E striking faults as well as their N30E-N40E conjugates (Fig. 8b). This suggests 605 that the Arpheuilles basin may be the lateral equivalent of the early Carboniferous Ancenis 606 basin.

608 6.2.5 The Aigurande Plateau and its connection with the Haut Bocage unit

609 This area consists in a stack of metamorphic nappes intruded by granitic plutons (Fig. 2).

610 Under cover, the Cholet fault delimits the northern contact of the high grade metamorphic

611 nappes with the Mauges nappe, composed of low grade micaschists (Fig. 8d).

612 In the northern part of the Aigurande Plateau, the Lower Gneiss Unit (LGU), is mainly 613 composed of low magnetic susceptibility and density micaschists and metagrauwackes (up 614 to $4 \times 10^{-4} \mathrm{SI}$ and $2.8 \mathrm{~g} / \mathrm{cm}^{3} ;$ Fig. 5), and intermediate magnetic and high density 615 amphibolite (from 5 to $9 \times 10^{-4} \mathrm{SI}, 3.01 \mathrm{~g} / \mathrm{cm}^{3}$ ). The Upper Gneiss Unit (UGU) was 616 discriminated from the LGU by both the high magnetic and density signatures (Fig. 6a) 617 deriving from the amphibolites within the leptynite-amphibolite complex (from $1.5 \times 10^{-2}$ to 5 $618 \times 10^{-2} \mathrm{SI}$ and $2.98 \mathrm{~g} / \mathrm{cm}^{3 ;}$ Fig. 5). Consequently, the LGU/UGU contact can be mapped 619 under the Paris Basin sedimentary cover, bounded to the north by the northern branch of 
620 the Cholet fault (Fig. 7a). The LGU micaschists are associated with the Haut Bocage unit

621 described in the field (Fig. 6b; Fig. 7a), which consist of a stack of metamorphic nappes,

622 refolded in an ENE-SSW striking antiform/synform succession, intruded by Carboniferous

623 granites (Fig. 7b).

624 The micaschists of the Para-autochtonous unit displaying low to intermediate magnetic 625 susceptibility and density (up to $4 \times 10^{-4} \mathrm{SI}$ and $2.68 \mathrm{~g} / \mathrm{cm}^{3}$ ), related to low to intermediate 626 magnetic and gravity signatures (Fig. 6a), has no characteristic signature that can be

627 mapped under the Paris Basin sedimentary cover.

628 In this area, granitic plutons belong to the Hercynian Mortagne - Marche leucogranites belt 629 (Vigneresse, 1988; Gapais et al., 1993; Vigneresse, 1999; Rolin and Colchen, 2001; Rolin 630 et al., 2009; Edel et al., 2015; Gapais et al., 2015). These granites are largely represented 631 in the Haut Bocage unit and Massif connection (Fig. 7a).

632

\subsubsection{The Poitou High: the Haut Bocage unit and the Confolentais area junction}

634 Largely represented in the field, in the Haut Bocage unit and the Confolentais area 635 (Fig. 6b), the low magnetic and gravity signatures (Fig. 6a) are related to granitic plutons 636 (from $0.8 \times 10^{-5}$ to $10^{-4} \mathrm{SI}$ and $2.65 \mathrm{~g} / \mathrm{cm}^{3}$; Fig. 5). Under cover, equivalent magnetic and 637 gravity signatures related to granitic plutons described in the Poitou High (from 2.5 to $6384 \times 10^{-5} \mathrm{SI}$ and $2.62 \mathrm{~g} / \mathrm{cm}^{3}$; Fig. 5), mark the connection between the southern part of the 639 Haut Bocage unit and Confolentais area (Fig. 7a). As largely recovered in boreholes (Fig. 640 6b), granitic plutons represent the main rocks of the substratum in this area (Fig. 7a). These 641 granitic plutons consist in leucomonzogranites, leucogranites, granodiorites and calk642 alkaline diorites. They belong to a granitic belt emplaced from late Devonian to early643 Carboniferous and are associated with the shearing of the various branches of the SASZ 
644 (see Rolin et al., 2009 for more information). Using the geophysical signatures of the

645 substratum (Fig. 6a), it is not possible to discriminate the various leucomonzogranites,

646 leucogranites and granodiorites.

647 Under the sedimentary cover, the southern part of the Poitou High is marked by punctual

648 high magnetic and gravity signatures (Fig. 6a) related to the calk-alkaline diorite plutons

649 exposed in the field, both in Confolentais area and Haut Bocage unit (Fig. 6b). These diorite 650 plutons emplaced at $373 \pm 10 \mathrm{Ma}$ (Cuney et al., 1993) and from $360 \pm 3 \mathrm{Ma}$ to $349 \pm 5 \mathrm{Ma}$

651 (Bertrand et al., 2001; Alexandre et al., 2002) for the Montcoutant and various Poitou High

652 diorite plutons, respectively, are associated with the dextral shearing of the SBSASZ (Fig.

653 8c) (see Rolin et al., 2009 for more information). In the southern Aigurande Plateau, Huriel 654 diorite intrusion (Fig. 8c) emplaced at $361 \pm 1$ Ma (Pin and Paquette, 2002) and post-date 655 the dextral shearing of the Marche fault (Rolin et al., 2009). Diorite plutons have consistent 656 high magnetic susceptibility and density (up to $1.5 \times 10^{-2} \mathrm{SI}$ and $2.80 \mathrm{~g} / \mathrm{cm}^{3}$ and from 3 to 6 $657 \times 10^{-3} \mathrm{SI}$, and $2.80 \mathrm{~g} / \mathrm{cm}^{3}$, respectively; Fig. 5). These basic rocks are discriminated i) from 658 the intermediate magnetic and low density signatures corresponding to the LGU host 659 micaschists, in the Haut Bocage unit, and ii) from the high magnetic and intermediate 660 signatures related to the metavolcanites belonging to the UGU (up to $0.3 \mathrm{SI}$; Fig. 5 ), in the 661 Confolentais area (Fig. 7a).

\section{7. Summary and Conclusion}

664 Our paper outlines the benefit of a joint interpretation of potential fields (high-resolution 665 aeromagnetic and gravity data) and petrophysical characterization (magnetic susceptibility 666 and density measurements on rock samples), in order to derive reliable lithological and 667 structural mapping of a buried substratum. 
668 In order to propose a geological map of the hidden substratum of the southwestern part of 669 the Paris Basin, our methodology, is divided into five successive stages: i) the potential field

670 data were processed, with the aim to get specific information (geophysical contrasts,

671 structural features...), ii) magnetic susceptibilities and densities were measured on field

672 rock samples along the eastern border of the Armorican Massif and the northern border of

673 the Massif Central, leading to a petrophysical library of lithologies, iii) using selected

674 magnetic and gravity maps, a map of geophysical signatures was synthetized using an

675 unsupervised classification, featuring 6-levels of magnetic/gravity intensities, iv) the

676 combined analysis and interpretation of magnetic and gravity trends with the synthetized

677 geophysical signatures, allowed extending the Variscan litho-structural units below the

678 Paris Basin sedimentary pile, v) relating the geophysical signatures to the petrophysical 679 characteristics (density and magnetization) within each litho-structural unit, allowed 680 interpreting a geological map of the substratum. This updated study reveals new geological

681 information: i) the limited eastward extension of Central Brittany, bordered to the east by the 682 NE-SW striking NBSASZ; ii) the eastward extension, along ca. $150 \mathrm{~km}$, of the Cholet fault, 683 interpreted as a major fault, delineating the northern limit of the Aigurande Plateau; iii) the 684 emphasis on a series of N150E-N160E and N30E striking normal Variscan fault, reactivated 685 during the tectonic history of the Paris Basin, especially controlling the opening of Permo686 Carboniferous basins; iv) the extension of the Nort-sur-Erdre fault considered as an 687 ophiolitic suture, documented by the presence of high magnetic and density rocks along the 688 southern part of the St-Georges-sur-Loire unit.

689 Overall, our methodology provides keys for extensive mapping of buried basement using 690 magnetic, gravity and petrophysical data. In the near future, this study will be extended to 691 the entire Paris Basin in order to propose a complete geological map of the pre-Mesozoic 692 substratum of the Paris Basin. 


\section{Acknowledgments}

694 This work is part of a PhD Thesis co-funded by Région Centre and BRGM. We thank an

695 anonymous reviewer and J.B. Edel for useful and constructive comments, which 696 contributed to improving the manuscript. Geophysical maps were drawn using GeosoftC 697 software.

698

699 References

700 Alexandre, P., Le Carlier de Veslud, C., Cuney, M., Ruffet, G., Virlogeux, D., Cheilletz, A., 701 2002. Datation 40Ar/39Ar des leucogranites sous couverture du complexe plutonique 702 703 de Charroux-Civray (Vienne). Comptes Rendus Geoscience 334, 1141-1148. doi:10.1016/S1631-0713(02)01859-X

704 Autran, A., Lameyre, J., 1980. Conclusions générales. Les granitoïdes de France. $705 \quad$ Mémoires BRGM 107, 87-99.

706 Autran, A., Lefort, J.P., Debeglia, N., Edel, J.B., Vigneresse, J.L., 1994. Gravity and 707 Magnetic Expression of Terranes in France and Their Correlation Beneath Overstep 708 Sequences, in: Chantraine, J., Rolet, J., Santallier, D.S., Piqué, A., Keppie, J.D. 709 (Eds.), Pre-Mesozoic Geology in France and Related Areas, IGCP-Project 233. $710 \quad$ Springer Berlin Heidelberg, pp. 49-72.

711 Ballèvre, M., Pinardon, J.-L., Kienast, J.-R., Vuichard J.-P., 1989. Reversal of Fe-Mg 712 partitioning between garnet and staurolite in eclogite-facies metapelites from the 713 Champtoceaux nappe (Brittany, France). Journal of Petrology 30, 1321-1349.

714 Ballèvre, M., Paris, F., Robardet, M., 1992. Corrélations ibéro-armoricaines au 715 Paléozoïque: une confrontation des données paléobiogéographiques et 716 tectonométamorphiques. Comptes Rendus de l'Académie des sciences. Série 2, 

1789.

719 Ballèvre, M., Marchand, J., Godard, G., Goujou, J.-C., Christian, J., Wyns, R., 1994. 720 Eo-Hercynian Events in the Armorican Massif, in: Chantraine, J., Rolet, J., Santallier, D.S., Piqué, A., Keppie, J.D. (Eds.), Pre-Mesozoic Geology in France and Related Areas, IGCP-Project 233. Springer Berlin Heidelberg, pp. 183-194.

Ballèvre, M., Lardeux, H., 2005. Signification paléoécologique et paléogéographique des 724 bivalves du Carbonifère inférieur du bassin d'Ancenis (Massif armoricain). Comptes Rendus Palevol 4, 109-121. doi:10.1016/j.crpv.2004.11.011.

Ballèvre, M., Bosse, V., Ducassou, C., Pitra, P., 2009. Palaeozoic history of the Armorican Massif: Models for the tectonic evolution of the suture zones. Comptes Rendus Géoscience 341, 174-201. doi:10.1016/j.crte.2008.11.009.

Baptiste, J., Martelet, G., Faure., Beccaletto, L., Perrin, J., 2015. Up-to-date regional gravity 730 and aeromagnetic data to unravel the geological patterns of the pre-Mesozoic substratum of the Paris Basin. Variscan 2015 : The Variscan belt : correlations and plate dynamics, Jun 2015, Rennes, France.

Beccaletto, L., Hanot, F., Serrano, O., Marc, S., 2011. Overview of the subsurface structural 738 Beccaletto, L., Capar, L., Serrano, O., Marc, S., 2015. Structural evolution and sedimentary 739 record of the Stephano-Permian basins occurring beneath the Mesozoic sedimentary 740 cover in the southwestern Paris basin (France). Bulletin de la Société Géologique de 741 France. 6, 429-450. 
742 Bernard-Griffiths, J., Peucat, J.J., Sheppard, S., Vidal, P., 1985. Petrogenesis of Hercynian leucogranites from the southern Armorican Massif: contribution of REE and isotopic (Sr, $\mathrm{Nd}, \mathrm{Pb}$ and $\mathrm{O})$ geochemical data to the study of source rock characteristics and ages. Earth and Planetary Science Letters 74, 235-250. doi:10.1016/0012-821X(85)90024-X

746

Berthé, D., Choukroune, P., Jegouzo, P., 1979. Orthogneiss, mylonite and non coaxial deformation of granites: the example of the South Armorican Shear Zone. Journal of Structural Geology 1, 31-42. doi:10.1016/0191-8141(79)90019-1

Bertrand, J.M., Leterrier, J., Cuney, M., Brouand, M., Stussi, J.M., Delaperrière, E., Virlogeux, D., 2001. Géochronologie U-Pb sur zircons de granitoïdes du Confolentais, du massif de Charroux-Civray (seuil du Poitou) et de Vendée. Géologie de la France 1, 167-189.

Bitri, A., Ballèvre, M., Brun, J.-P., Chantraine, J., Gapais, D., Guennoc, P., Gumiaux, C., Truffert, C., 2003. Imagerie sismique de la zone de collision hercynienne dans le Sud-Est du Massif armoricain (projet Armor 2/programme Géofrance 3D). Comptes Rendus Géoscience 335, 969-979. doi:10.1016/j.crte.2003.09.002.

Blakely, R.J. 1996. Potential Theory in Gravity and Magnetic Applications (Cambridge University Press).

Bonijoly, D., Perrin, J., Truffert, C., Asfirane, F., 1999. Couverture géophysique aéroportée du Massif armoricain, magnétisme et radiométrie spectrale. Rapport BRGM R 40471.

Bosse, V., Feraud, G., Ruffet, G., Ballèvre, M., Peucat, J.-J., De Jong, K., 2000. Late Devonian subduction and early-orogenic exhumation of eclogite-facies rocks from the Champtoceaux Complex (Variscan belt, France). Geological Journal. 35, 297-325. doi:10.1002/gj.864. 
765 Burg, J.-P., 1981. "Tectonique tangentielle hercynienne en Vendée littorale : Signification des linéations d'étirement E-W dans les porphyroïdes à foliation horizontale." Comptes Rendus de l'Académie des Sciences de Paris, 293, 849-854.

768 Cabanis, B., Wyns, R., 1986. Le volcanisme précambrien des Mauges (sud-est du Massif armoricain) et ses caractères géochimiques. Hercynica, Rennes, (II), 1, 71-78.

770 Cartannaz, C., Rolin, P., Le Métour, J., Fabbri, O., 2006. Fammenian-Tournaisian dextral 771 ductile shear in the French Variscan belt. Comptes Rendus Géoscience 338, 214-221. 772 doi:10.1016/j.crte.2005.12.003

773 Cartier, C., Faure, M., Lardeux, H., 2001. The Hercynian Orogeny in the South Armorican 774 Massif (Saint-Georges-sur-Loire Unit, Ligerian Domain, France): rifting and welding of continental stripes. Terra Nova. 13, 143-149.

Cartier, C., Faure, M., 2004. The Saint-Georges-sur-Loire olistostrome, a key zone to understand the Gondwana-Armorica boundary in the Variscan belt (Southern Brittany,

783 Cavet, P., Arnaud, A., Barbaroux, L., Blaise, J., Brossé, R., Chauris, L., Gruet, M., Lardeux, 784 785 France). Int. J. Earth Sci. 93, 945-958. doi:10.1007/s00531-004-0398-3.

Cavet, P., Gruet, M., Pillet, J., 1966. Sur la présence du Cambrien à Paroxides à Cléré-surLayon (Maine et Loire) dans le Nord-Est du Bocage vendéen (Massif Armoricain). Comptes Rendus Hebdomadaires des séances de l'Académie des Sciences. 263, 786 787 788 H., Rivière, J.-M., 1970. Carte géologique de la France (1/50000), feuille Chalonnessur-Loire (453), BRGM, Orléans.

Cavet, P., Lardeux, H., Philippot, A., 1971. Ordovicien et Silurien aux environs de Montjean et Chalonnes (Maine-et-Loire, Sud-Est du Massif armoricain). Mémoires BRGM 73, 199-212. 
789 Cavet, P., Arnaud, A., Blaise, J., Brossé, R., Chauris, L., Gruet, M., Lardeux, H., 1976. $790 \quad$ Carte géologique de la France (1/50000), feuille Angers (454), BRGM, Orléans.

791 Chantraine, J., Autran, A., Cavelier, C. and collab., 2003. Carte Géologique de la France au 792 $1 / 1000000^{\mathrm{e}}$. BRGM (6 $6^{\text {ème }}$ édition), Orléans. France.

793 Chauris, L., and Lucas, G., 1964. Les environs de Bécon-les-Granits (Maine-et-Loire) 794 (Feuille d'Ancenis au 80.000e). Bulletin de la Carte Géologique de France, LX-277 795 25-33.

796 Chauris, L., 1969. Sur un important accident structural dans le Nord-Ouest de l'Armorique. 797 Comptes Rendus de l'Académie des Sciences. 268, 2859-2861.

798 Clark, D., Emerson, D., 1991. Notes on rock magnetization characteristics in applied 799 geophysical studies. Exploration Geophysics 22, 547-555. doi:10.1071/EG991547.

800 Corpel, J., Weber, C., 1970. Contribution de l'étude de l'aimantation rémanente à la 801 gîtologie du synclinal ferrifère de Segré. Rapport BRGM/70-SGN-029-GPH, 23 pp.

802 Cuney, M., Stussi, J.-M., Brouand, M., Dautel, D., Michard, A., Gros, Y., Poncet, D., 803 Bouton, P., Colchen, M., Vervialle, J.-P., 1993. Géochimie et géochronologie U/Pb 804 des diorites quartziques du Tallud et de Moncoutant: nouveaux arguments pour une 805 806 807 extension de la Ligne Tonalitique Limousine en Vendée. Comptes Rendus de l'Académie des Sciences. Série 2, Mécanique, Physique, Chimie, Sciences de l'univers, Sciences de la Terre 316, 1383-1390.

808 Dearing, J., 1999. Magnetic susceptibility, in: Environmental Magnetism: A Practical Guide. 809 Quaternary Research Association London, pp. 35-62.

810 Debeglia, N., Weber, C., 1980. Synthèse géologique du bassin de Paris. Mémoires du 811 BRGM n¹02. 
812 Debeglia, N., Weber, C., 1985. Geologic mapping of the basement of the Paris basin 813 (France) by gravity and magnetic data interpretation. In: The Utility of regional gravity 814 and magnetic anomaly maps, (ed. W.J. Hinze). Society of Exploration Geophysicists.

815 Ducassou, C., Ballèvre, M., Lardeux, H., Robin, C., 2011. Evidence for pre-orogenic, Early 816 Devonian rifting in the Variscan belt: stratigraphy and structure of the Palaeozoic cover 817 of the Mauges Unit (Upper Allochthon, Armorican massif, France). Int. J. Earth Sci. 818 (Geol Rundsch) 100, 1451-1475. doi:10.1007/s00531-010-0605-3.

819 Edel, J.B., 2008. Structure et nature du socle anté-permien du Bassin de Paris d'après les 820 données gravimétriques et magnétiques - Le problème de l'Anomalie Magnétique du $821 \quad$ Bassin de Paris (AMBP). Géochronique, 105, pp. 31-37.

822 Edel, J.-B., Schulmann, K., Lexa, O., Diraison, M., Géraud, Y., 2015. Permian clockwise 823 rotations of the Ebro and Corso-Sardinian blocks during Iberian-Armorican oroclinal bending: Preliminary paleomagnetic data from the Catalan Coastal Range (NE Spain).

826 Elkins, T., 1951. The second derivative method of gravity interpretation. Geophysics. 16, 827 29-50. doi:10.1190/1.1437648.

828 Fairhead, J.D., Salem, A., Cascone, L., Hammill, M., Masterton, S., Samson, E., 2011. New 829 developments of the magnetic tilt-depth method to improve structural mapping of

832 Faure, M., Prost, A.E., Lasne, E., 1990. Deformation ductile extensive d'age namuro833 westphalien dans le plateau d'Aigurande, Massif central francais. Bulletin de la Société 834 Géologique de France VI, 189-197. doi:10.2113/gssgfbull.VI.1.189.

835 Faure M., Leloix C., Roig J.Y., 1997. L'évolution polycyclique de la chaîne hercynienne. 836 Bulletin de la Société géologique de France 168, 695-705. 
837 Faure, M., and Cartier, C., 1998. Déformations ductiles polyphasées dans l'antiforme orthogneissique de St-Clément-de-la-Place (unité de Lanvaux, Massif armoricain). Comptes Rendus de l'Académie des Sciences - Series IIA - Earth and Planetary Science 326, 795-802. doi:10.1016/S1251-8050(98)80245-0.

841 Faure, M., Mezeme, E.B., Duguet, M., Cartier, C., Talbot, J.-Y., 2005. Paleozoic tectonic evolution of medio-Europa from the example of the French Massif Central and Massif Armoricain. Journal of the virtual Explorer 19, 1-25.

844 Faure, M., Bé Mézème, E., Cocherie, A., Rossi, P., Chemenda, A., Boutelier, D., 2008. 845 Devonian geodynamic evolution of the Variscan Belt, insights from the French Massif Central and Massif Armoricain. Tectonics 27, TC2005. doi:10.1029/2007TC002115.

Faure M., 2014. Le substratum de la France métropolitaine : de la formation du Gondwana à la constitution de la Pangée, une histoire de 600 Ma. Géologues, 180, pp. 13-21.

Gapais, D., Lagarde, J.L., Le Corre, C., Audren, C., Jegouzo, P., Casas Sainz, A., Van Den Driessche, J., 1993. La zone de cisaillement de Quiberon: témoin d'extension de la chaine varisque en Bretagne méridionale au Carbonifère. Comptes Rendus de l'Académie des Sciences, Paris, série II 316, 1123-1129.

Gapais, D., Brun, J.-P., Gumiaux, C., Cagnard, F., Ruffet, G., Veslud, C.L.C.D., 2015. 859 Extensional tectonics in the Hercynian Armorican belt (France). An overview. Bulletin de la Société Géologique de France 186, 117-129. doi:10.2113/gssgfbull.186.2-3.117

Gébelin, A., Brunel, M., Monié, P., Faure, M., Arnaud, N., 2007. Transpressional tectonics and Carboniferous magmatism in the Limousin, Massif Central, France: Structural and 40Ar/39Ar investigations. Tectonics 26.

Gérard, A., and Griveau, P., 1972. Interpretation quantitative en gravimétrie ou magnétisme à partir de cartes transformées en gradient vertical. Geophysical Prospecting 20, 459481. doi:10.1111/j.1365-2478.1972.tb00648.x. 
862 Goguel, J., and Francia, 1954. Levé gravimétrique détaillé du Bassin parisien. Ministère de 863 I'Industrie et de l'Energie. Direction des Mines. Imprimerie Nationale.

864 Goguel, J., 1972. Tendances modernes dans l'interprétation géologique des données 865 gravimétriques. Bull. BRGM 43-50.

866 Guillocheau, F., Robin, C., Allemand, P., Bourquin, S., Brault, N., Dromart, G., Friedenberg, 867 R., Garcia, J.-P., Gaulier, J.-M., Gaumet, F., others, 2000. Meso-Cenozoic geodynamic 868 evolution of the Paris Basin: 3D stratigraphic constraints. Geodinamica Acta 13, 189_ 869245

870 Houlgatte, E., Le Hérissé, A., Pelhate, A., Rolet, J., 1988. Evolution géodynamique du 871 Bassin carbonifère de Laval. Géologie de la France 1, 27-46.

872 Jégouzo, P., 1980. The South Armorican Shear Zone. Journal of Structural Geology, Shear 873 zones in rocks 2, 39-47. doi:10.1016/0191-8141(80)90032-2.

874 Lardeux, H., Cavet, P., 1994. Paleozoic of the Ligerian Domain, in: Chantraine, J., Rolet, J., 875 Santallier, D.S., Piqué, A., Keppie, J.D. (Eds.), Pre-Mesozoic Geology in France and 876 Related Areas, IGCP-Project 233. Springer Berlin Heidelberg, pp. 152-156.

877 Lecoanet, H., Lévêque, F., Segura, S., 1999. Magnetic susceptibility in environmental 878 applications: comparison of field probes. Physics of the Earth and Planetary Interiors 879 115, 191-204. doi:10.1016/S0031-9201(99)00066-7.

880 Le Corre, C., Auvray, B., Ballèvre, M., \& Robardet, M., 1991. Le massif 881 armoricain. Scientifical Geological Bulletin. 44, 31-103.

882 Le Gall, J., Vernhet, Y., Lacquement, F., Gauquelin, J.-L., Robert, A., Cocherie, A., 883 Naveau, J, 2011 - Notice explicative, Carte géologique de France (1/50 000), feuille 884 Laval (319). Orléans : BRGM, 261 p. Carte géologique par Le Gall J., Gigot P., 885 Savaton P., Lacquement F., Poprawsky Y., Vernhet Y. (2011). 
886 Le Hébel, F., Vidal, O., Kienast, J.-R., Gapais, D., 2002. Les « Porphyroïdes » de Bretagne 887 méridionale: une unité de HP-BT dans la chaîne hercynienne. Comptes Rendus 888 Geoscience 334, 205-211. doi:10.1016/S1631-0713(02)01746-7.

889 Le Hérissé, A., and Plaine, J., 1982. Volcanisme basique dans le Carbonifère inférieur du 890 Synclinorium de Laval (Massif armoricain, France). Comptes Rendus de l'Académie 891 des Scences de Paris, 294, 1199-1202.

892 Lienhardt, M.J., 1961. Étude stratigraphique, pétrographique et structurale du socle anté 893 permien du bassin de Paris. Annales de la Société Géologique du Nord 81, 233-241.

894 Marchand, J., 1981. Ecaillage d'un "mélange tectonique" profond: le complexe 895 cristallophyllien de Champtoceaux (Bretagne méridionale). Comptes Rendus de 896 l'Académie des Sciences de Paris 293, 223-228.

897 Martelet, G., Debeglia, N., Truffert, C., 2002. Updating and validating the French gravity 898 terrain corrections out to a distance of $167 \mathrm{~km}$. Comptes Rendus Géoscience. 334, $899 \quad 449-454$.

900 Martelet, G., Calcagno, P., Gumiaux, C., Truffert, C., Bitri, A., Gapais, D., Brun, J.P., 2004. 901 Integrated 3D geophysical and geological modelling of the Hercynian Suture Zone in 902 the Champtoceaux area (south Brittany, France). Tectonophysics 382, 117-128. 903 doi:10.1016/j.tecto.2003.12.009.

904 Martelet, G., Pajot, G., Debeglia, N., 2009. Nouvelle carte gravimétrique de la France; 905 RCGF09 - Réseau et Carte Gravimétrique de la France, 2009. Rapport BRGM/RP$906 \quad 57908-F R, 77$ p.

907 Martelet, G., Perrin, J., Truffert, C., Deparis, J., 2013. Fast mapping of magnetic basement 908 depth, structure and nature using aeromagnetic and gravity data: combined methods 909 and their application in the Paris Basin: Fast mapping of a buried basement using 
magnetic and gravity data. Geophysical Prospecting 61, 857-873. doi:10.1111/13652478.12024.

912 Martínez Catalán J.R., 2012. The Central Iberian arc, an orocline centered in the Iberian 913 Massif and some implications for the Variscan belt. Int. J. Earth Sci. 101, 1299-1314. 914 doi:10.1007/s00531-011-0715-6.

915 Mathieu, G., 1943. Révision de la feuille de Saumur au 1/80000ème. Bulletin du Service de 916 la Carte géologique de France, 212, p119-129.

917 Mathieu, G., 1958. Les grandes lignes de la Vendée. Ibid., 253, 46p.

918 Matte, P., 1986. Tectonics and plate tectonics model for the Variscan belt of Europe. 919 Tectonophysics 126, 329-374. doi:10.1016/0040-1951(86)90237-4.

920 Matte, P., Hirn, A., 1988. Seismic signature and tectonic cross section of the Variscan crust 921 in western France. Tectonics 7, 141-155.

922 Matte, P., 1991. Accretionary history and crustal evolution of the Variscan belt in Western 923 Europe. Tectonophysics 196, 309-337. doi:10.1016/0040-1951(91)90328-P.

924 Mégnien, C., 1980. Synthèse géologique du Bassin de Paris, I, Stratigraphie et 925 paléogéographie, Mémoires du BRGM, 101, 466pp.

926 Miller, H. G. and Singh, V., 1994. Potential field tilt; a new concept for location of potential 927 field sources. Journal of Applied Geophysics. 32, 213-217.

928 Peiffer, M.-T., 1986. La signification de la ligne tonalitique du Limousin. Son implication 929 dans la structuration varisque du Massif Central français. Comptes Rendus de 930 l'Académie des Sciences. Série 2, Mécanique, Physique, Chimie, Sciences de 931 l'univers, Sciences de la Terre 303, 305-310.

932 Perrodon, A. and Zabek, J., 1990. Paris Basin; Interior cratonic basins. AAPG Memoir, 51, $933 \quad 633-679$. 
934 Pin, C., and Paquette, J.-L., 2002. Le magmatisme basique calcoalcalin d'âge dévono935 dinantien du nord du Massif Central, témoin d'une marge active hercynienne: 936 arguments géochimiques et isotopiques $\mathrm{Sr} / \mathrm{Nd}$. Geodinamica Acta $15,63-77$. 937 doi:10.1016/S0985-3111(01)01079-8.

938 Pomerol, C., 1978. Paleogeographic and structural evolution of the Paris Basin, from the 939 Precambrian to the present day, in relation to neighboring regions. Geologie En $940 \quad$ Mijnbouw Journal of Geosciences, 57, 533-543.

941 Quenardel, J.-M., Rolin, P., 1984. Palaeozoic evolution of the Plateau d'Aigurande (NW 942 Massif Central, France). Geological Society, London, Special Publications 14, 63-70. 943 doi:10.1144/GSL.SP.1984.014.01.06.

944 Rolin, P., Colchen, M., 2001. Les cisaillements hercyniens de la Vendée au Limousin. 945 Géologie de la France, $\mathrm{n}^{\circ}$ 1-2. 87-116.

946 Rolin, P., Marquer, D., Colchen, M., Cartannaz, C., Cocherie, A., Thiery, V., Quenardel, J.947 M., Rossi, P., 2009. Famenno-Carboniferous (370-320 Ma) strike slip tectonics 948 monitored by syn-kinematic plutons in the French Variscan belt (Massif Armoricain and 949 French Massif Central). Bulletin de la Société Géologique de France 180, 231-246. 950 doi:10.2113/gssgfbull.180.3.231.

951 Tartèse, R., Boulvais, P., Poujol, M., Vigneresse, J.-L., 2011a. Granite petrogenesis 952 revealed by combined gravimetric and radiometric imaging. Tectonophysics $501,98-$ 953 103. doi:10.1016/j.tecto.2011.02.003

954 Tartèse, R., Poujol, M., Ruffet, G., Boulvais, P., Yamato, P., Košler, J., 2011b. New U-Pb 955 zircon and 40Ar/39Ar muscovite age constraints on the emplacement of the Lizio syn956 tectonic granite (Armorican Massif, France). Comptes Rendus Geoscience 343, 443957 453. doi:10.1016/j.crte.2011.07.005 
958 Taylor, H.L., Mason, M.C., 1972. A Systematic Approach to Well Surveying Calculations. 959 Society of Petroleum Engineers Journal 12, 474-488. doi:10.2118/3362-PA.

960 Théveniaut, H., Clarke, B., 2013. Large scale magnetic susceptibility soil mapping: a proxy 961 for geological mapping and exploration from Bogoso (Ghana). Exploration Geophysics 962 44, 48. doi:10.1071/EG12019.

963 Thiéblemont, D., Cabanis, B., Le Métour, J., 1987. Étude géochimique d'un magmatisme 964 de distension intracontinentale: la série bimodale ordovico-silurienne du Choletais 965 (Massif vendéen), Géologie de la France 1, 65-76.

966 Thiéblemont, D., Guerrot, C., Le Métour, J., Jézéquel, P., 2001. Le complexe de Cholet967 Thouars: un ensemble volcano-plutonique cambrien moyen au sein du bloc 968 précambrien des Mauges. Géologie de la France, n¹-2. 7-17.

969 Thiéblemont, D., Augier, R., Ferry, J.-N., Laurent-Charvet, S., Maleyx, C., Ravoux, A., 970 Lebret, P., Guerrot, C., Chretien, P., 2011 - Notice explicative, Carte géologique de. 971 France (1/50 000), feuille Vihiers (511). Orléans : BRGM, 122 p.

972 Trautmann, F., Lacquement, F., Vernhet, Y., Pivette, B., avec la collaboration de Cocherie 973 A., Guerrot C., Thiéblemont D., Tegyey M., Denis E., 2011. - Notice explicative, Carte 974 975 géologique de France (1/50 000), feuille Vitré (318). Orléans : BRGM, 131 p. Carte 976 Truffert, C., Gumiaux, C., Chantraine, J., Perrin, J., Galdeano, A., Gapais, D., Ballèvre, M., 977 Asfirane, F., Guennoc, P., Brun, J.-P., 2001. Levé géophysique aéroporté dans le Sud978 Est du Massif armoricain (programme GéoFrance3D Armor2). Magnétisme et 979 radiométrie spectrale. Comptes Rendus de l'Académie des Sciences-Series IIA-Earth 980 and Planetary Science 333, 263-270. 
981 Turrillot, P., Augier, R., Faure, M., 2009. The top-to-the-southeast Sarzeau shear zone and 982 its place in the late-orogenic extensional tectonics of southern Armorica. Bulletin de la 983 Société Géologique de France 180, 247-261. doi:10.2113/gssgfbull.180.3.247

984 Venkateswarlu, N.B., Raju, P.S.V.S.K., 1992. Fast isodata clustering algorithms. Pattern 985 Recognition 25, 335-342. doi:10.1016/0031-3203(92)90114-X

986 Verduzco, B., Fairhead, J.D., Green, C.M., MacKenzie, C., 2004. New insights into 987 magnetic derivatives for structural mapping. The Leading Edge 23, 116-119.

988 Vernhet, Y., Plaine, J., Trautmann, F., Pivette, B., avec la collaboration de Chevremont, P., 989 Bourdillon, C., Cocherie, A., 2009 - Notice explicative, Carte géologique de France 990 (1/50 000), feuille Cossé-le-Vivien (355). Orléans : BRGM, 222 p. Carte géologique 991 par Vernhet, Y., Plaine, J., Trautmann, F., Clément J.P., 2009.

992 Vidal, P., 1980. L'évolution polyorogénique du Massif Armoricain : apport de la 993 géochronologie et de la géochimie isotopique du strontium. Mémoire de la Société 994 géologique Minérale de Bretagne, Rennes, 21,162-958

995 Vigneresse, J.-L., Brun, J.-P., 1983. Les leucogranites armoricains marqueurs de la 996 deformation regionale; apport de la gravimetrie. Bulletin de la Société Géologique de 997 France S7-XXV, 357-366. doi:10.2113/gssgfbull.S7-XXV.3.357

998 Vigneresse, J.-L., 1988. La fracturation post-hercynienne du Massif armoricain d'après les 999 données géophysiques. Géologie de la France 4, 3-10.

1000 Vigneresse, J.L., 1999. Intrusion level of granitic massifs along the Hercynian belt: 1001 balancing the eroded crust. Tectonophysics 307, 277-295. doi:10.1016/S0040$1002 \quad 1951(99) 00104-3$

1003 Virlogeux, D., Roux, J. ets Guillemot, D., 1999. Apport de la géophysique à la connaissance 1004 géologique du Massif de Charroux-Civray et du socle Poitevin. Dans « Etude du Massif 
de Charroux-Civray ». Actes Journées Sciences CNRS-ANDRA, Poitiers, 13-14. $1006 \quad 10,33-61$.

1007 Watts, M.S., and Williams, G.D., 1979. Faults rocks as indicators of progressive shear 1008 deformation in the Guingamp region, Brittany. Journal of Structural Geology, 1, 3231009332

1010 Weber, C., 1971. Le socle antépermien sous la bordure sud du bassin de Paris d'après les 1011 données géophysiques. Bulletin BRGM, section I n³, 177-189.

1012 Weber, C., 1973. Le socle antétriasique sous la partie sud du Bassin de Paris d'après les 1013 données géophysiques. Bulletin BRGM, sect. II, n³ et 4, 219-343.

1014 Wyns, R., Le Métour, J., 1983. Le Précambrien du massif vendéen. Etude détaillée de deux 1015 coupes de référence (coupes de l'Evre et de la Divatte) et synthèse des données 1016 récentes. Document BRGM, 68.

1017 Wyns, R., Lardeux, H., Moguedet, G., Duermael, G., Gruet, M., Biagi, R. avec la 1018 collaboration de Ballèvre, M., Chevremont, P., 1998. Notice explicative, carte 1019 géologique de la France (1/50 000), feuille Chemillé (483). BRGM, Orléans, 72 p. 


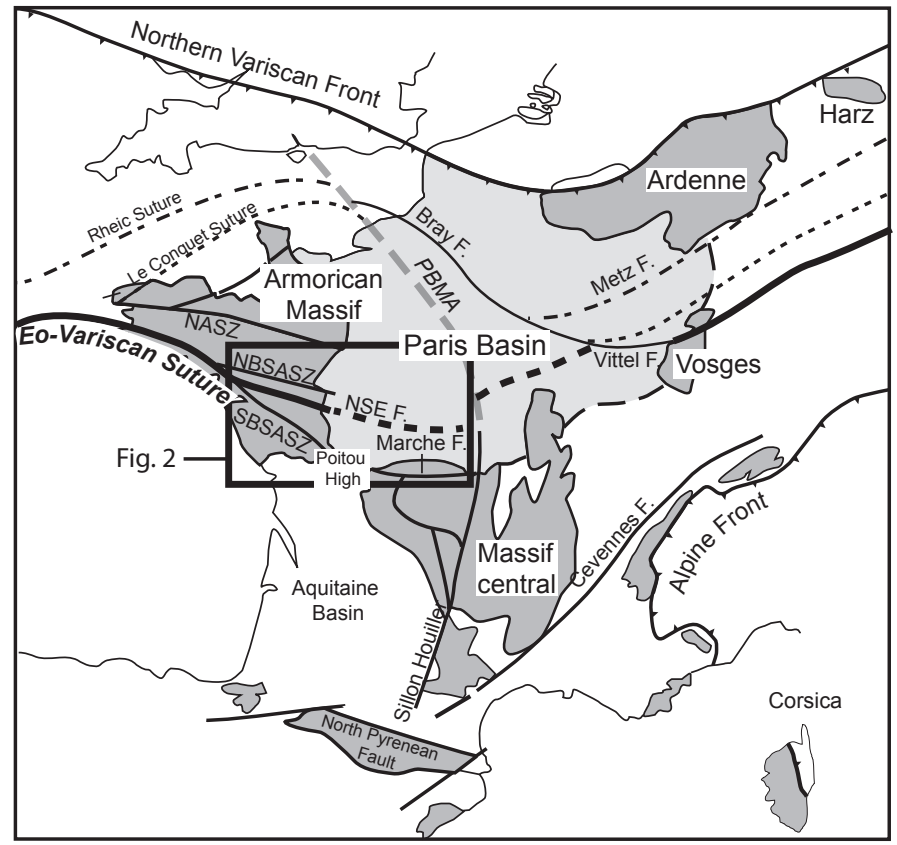

Fig. 1: Map of the Pre-Permian basement in France with Variscan sutures (modified from Faure, 2014). In dark grey: outcrops of the Variscan basement. NASZ: North Armorican Shear Zone, NBSASZ: Northern Branch of the South Armorican Shear Zone, SBSASZ: Southern Branch of the South Armorican Shear Zone, NSE F: Nort sur-Erdre Fault corresponding to the Eo-Variscan suture, PBMA: Paris Basin Magnetic Anomaly. In light grey: outcrop of the Meso-Cenozoic Paris Basin. 


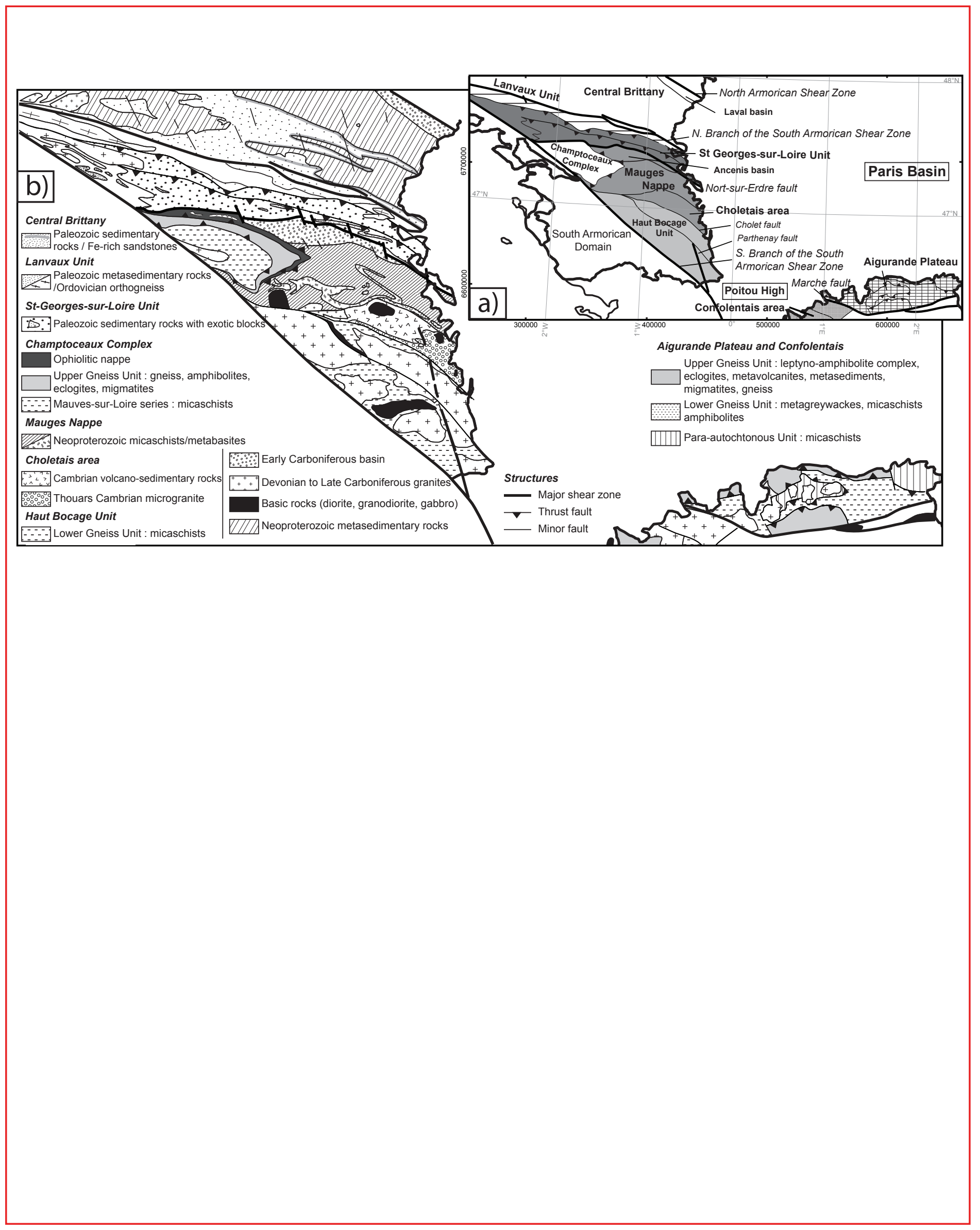

Fig. 2: Geological map of the southeastern part of the Armorican Massif and the northwestern part of the Massif Central: a) Major structures and litho-structural unit delimitations, b) Main lithologies within the litho-structural units (modified from Chantraine et al., 2003). 

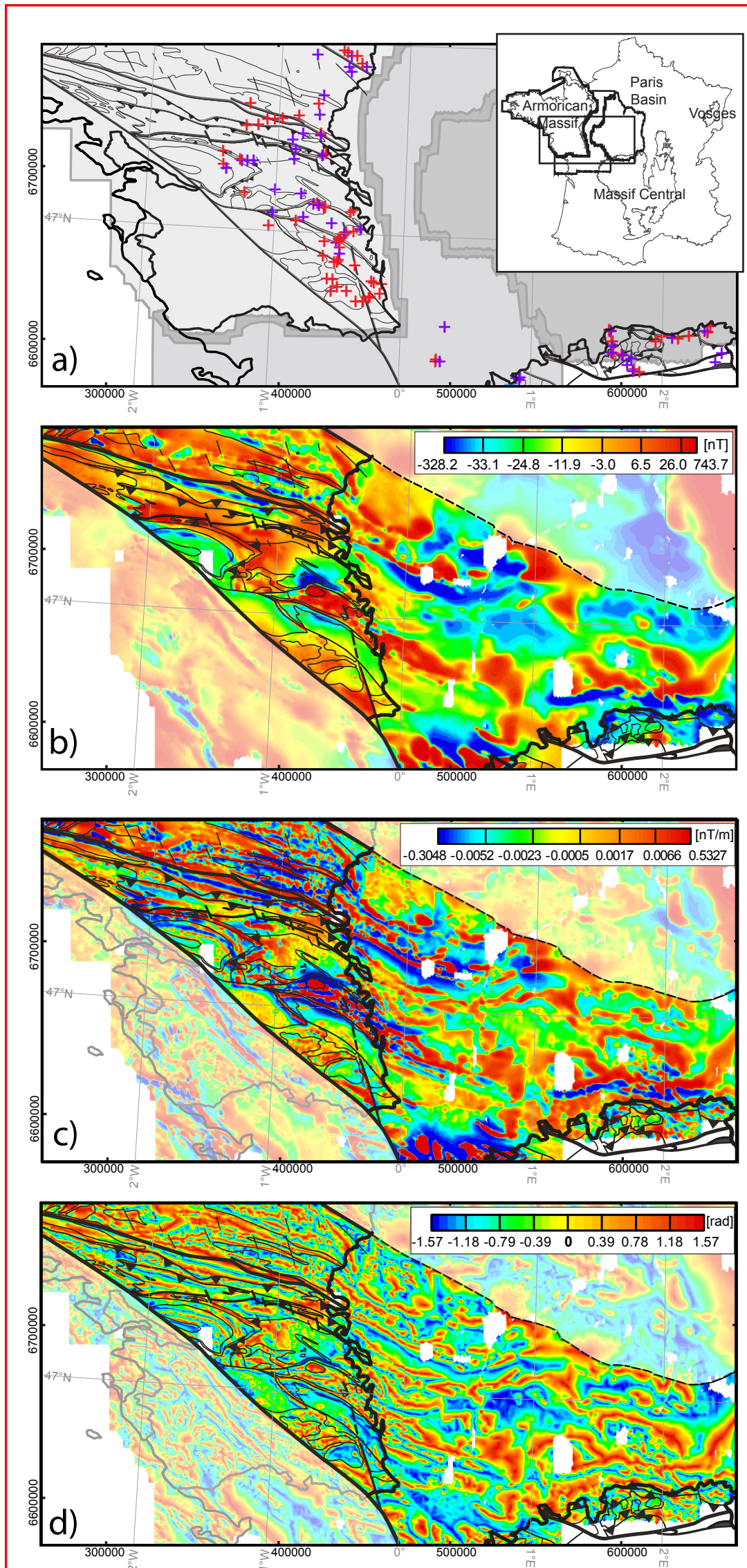

Fig. 3: a) Location map of the three aeromagnetic surveys used in this study. From west to east: Brittany, Pays de Loire (PaL), Région Centre. Crosses: location of the petrophysical field samples: in red: magnetic susceptibility only, in purple: magnetic susceptibility and density. b) Map of the magnetic anomaly reduced to the pole. c) Map of the magnetic vertical gradient. d) Map of the magnetic tilt derivative. Structural and lithological contours (thin black lines) and massif boundaries (thick black lines) are superimposed (modified from Chantraine et al., 2003). 


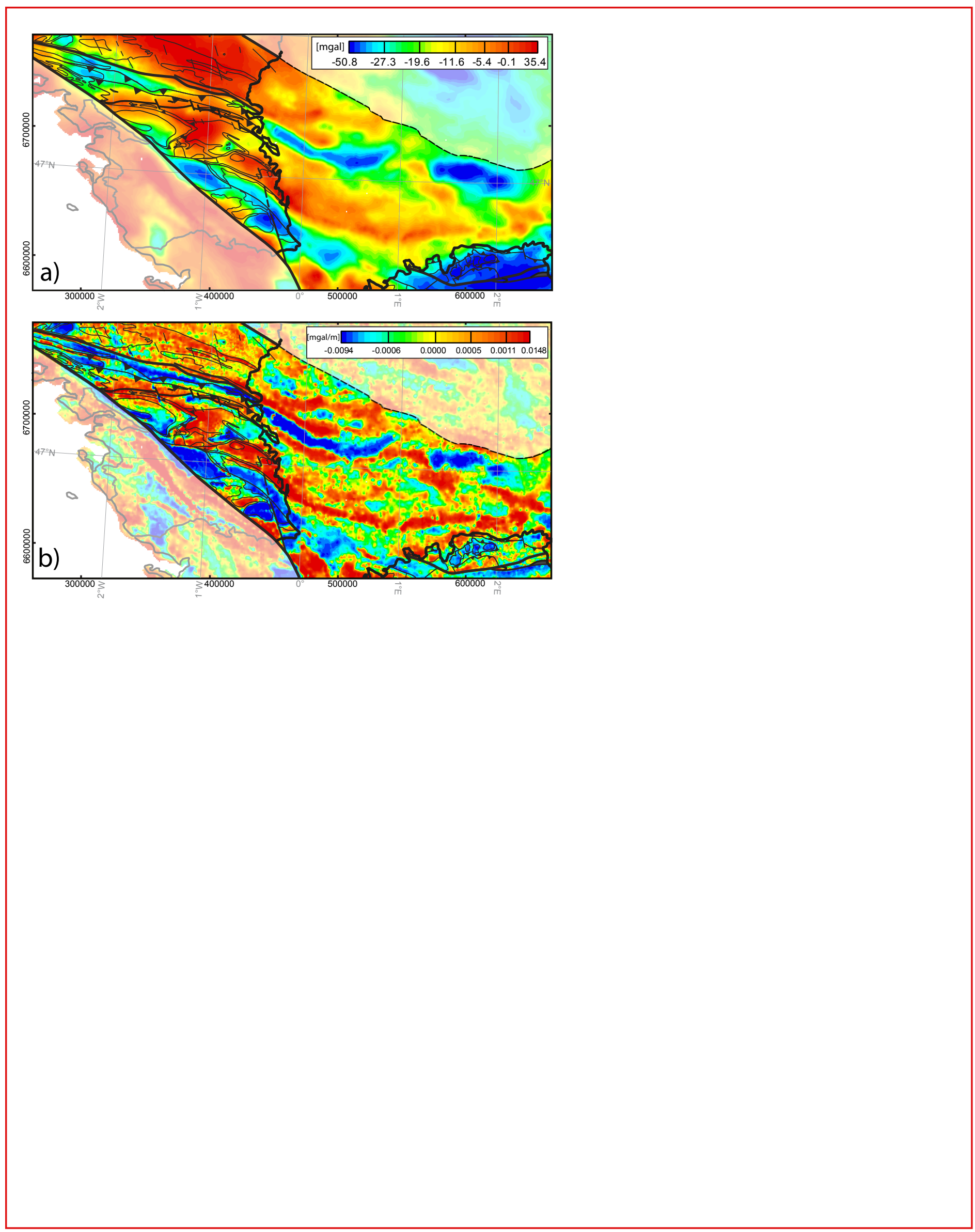

Fig. 4: a) Map of the Bouguer anomaly. b) Map of the vertical gradient of the Bouguer anomaly. Structural and lithological contours (thin black lines) and massif boundaries (thick black lines) are superimposed (modified from Chantraine et al., 2003). 


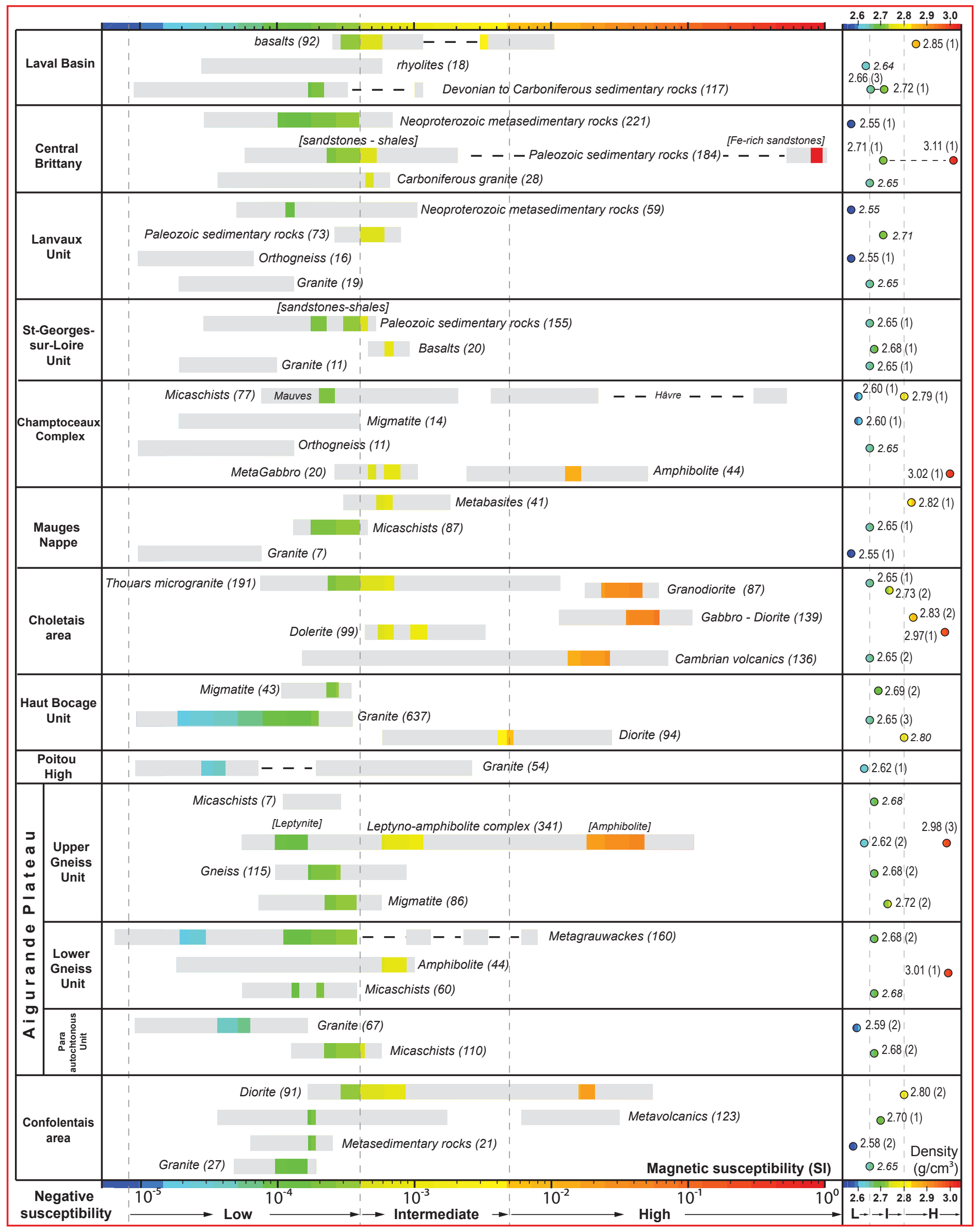

Fig. 5: Magnetic susceptibilities and average density values of the main lithologies sampled in the field, within each litho-structural unit. L: Low, I: Intermediate; H: High densities: refer to the text for explanations. In brackets: number of magnetic susceptibility measurements and number of density samples. Location of the sampling sites is documented in Fig. 3a. 


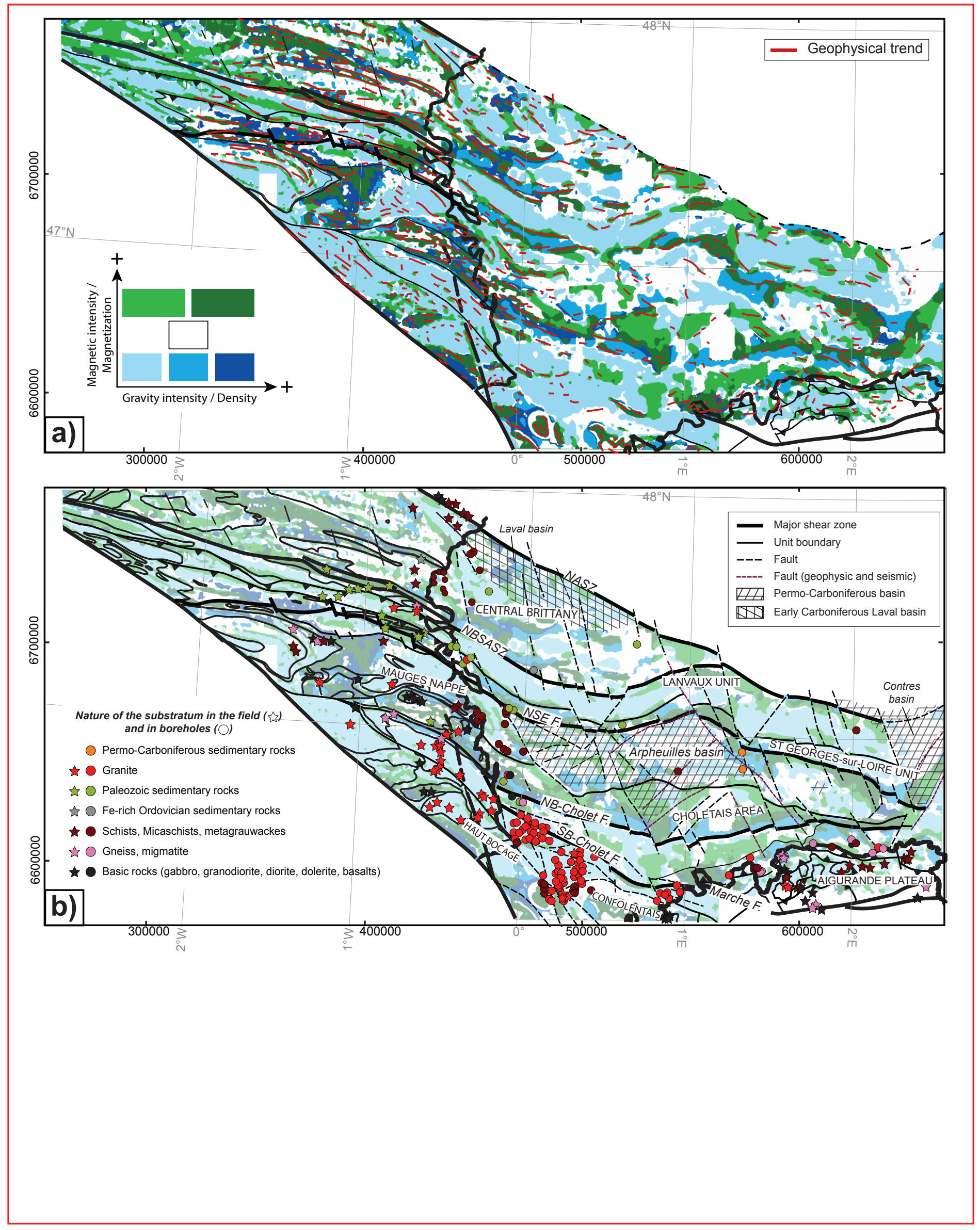

Fig. 6: a) Map of synthetized geophysical signatures resulting from the classification of the magnetic (magnetic anomaly reduced to the pole and magnetic tilt derivative) and gravity (vertical gradient of the Bouguer anomaly) signatures. Magnetic and gravity trends are superimposed (red lines). b) Interpretative structural sketch map of the Pre-Mesozoic substratum, of the southwestern part of the Paris Basin, with the location of the Permo-Carboniferous basins, the lithology of the studied outcrops (colored stars) and the lithology of the substratum in boreholes (colored circles). 


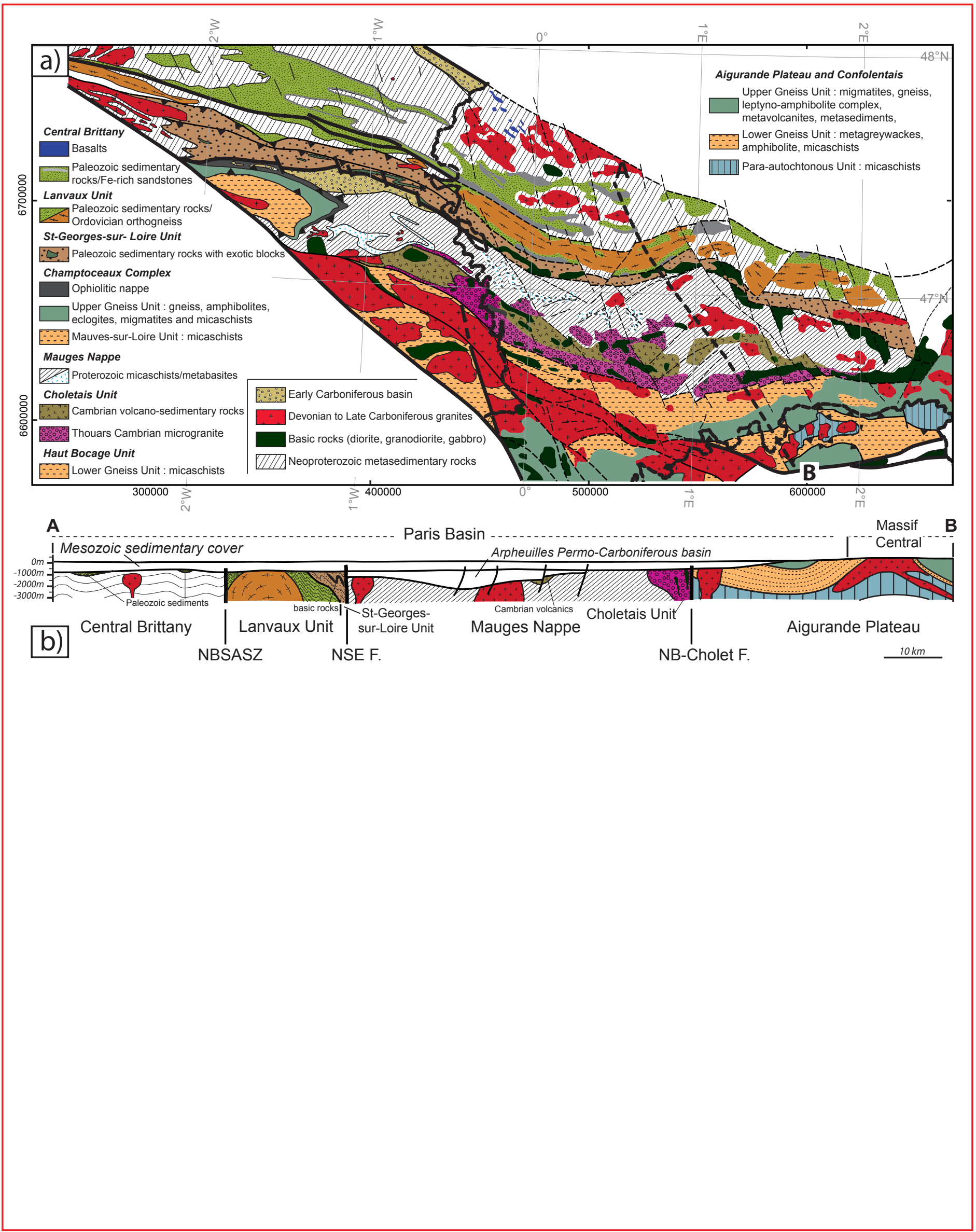

Fig. 7: a) Interpretative geological map of the Pre-Mesozoic substratum of the southwestern part of the Paris Basin. This map synthesizes the information coming from the potential field data (aeromagnetic and gravity enhanced maps), the classified geophysical signatures, the structural sketch map and the petrophysical characteristics of rock samples. For clarity reasons, Permo-Carboniferous basins are not represented in this map. The thick black dotted line locates the cross section presented in Fig.7b.

b) Interpretative geological cross-section of the Pre-Mesozoic substratum of the southwestern part of the Paris Basin inferred from the geophysical information processed in this study, and the extension of the structures known in the field. 

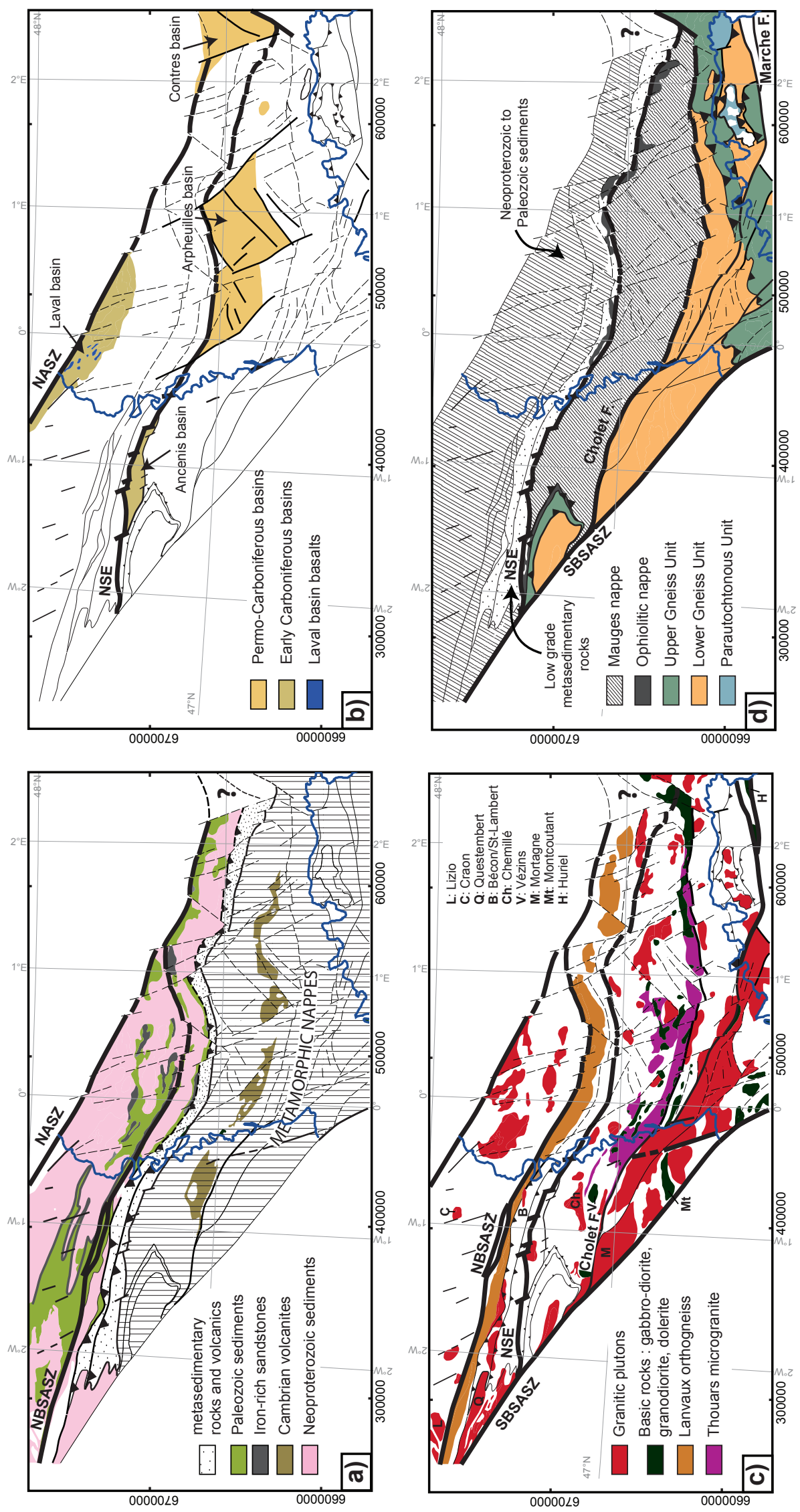

Fig. 8: Decomposition of the geological map into its main lithological ensemble: a) Sedimentary rocks and volcanites; b) Permo-Carboniferous basins, using geophysical and seismic data (modified from Beccaletto et al., 2015); c) magmatic intrusions; d) metamorphic nappes. Blue lines : massif boundaries (modified from Chantraine et al., 2003) 